\title{
Linking Cluster Characteristics and Organizational Capabilities for Sustainability-Framework Development and Application
}

\author{
Maria Clara da Cunha Bezerra*(D), Cláudia Fabiana Gohr*(D) and Sandra Naomi Morioka (D) \\ Departamento de Engenharia de Produção, Universidade Federal da Paraíba, João Pessoa 58.051-970, Brazil; \\ sandra.morioka@academico.ufpb.br \\ * Correspondence: mariaclarabezerraa@hotmail.com (M.C.d.C.B); claudiagohr@ct.ufpb.br (C.F.G.); \\ Tel.: +55-83-3216-7549 (C.F.G.)
}

check for updates

Citation: Bezerra, M.C.d.C.; Gohr, C.F.; Morioka, S.N. Linking Cluster Characteristics and Organizational Capabilities for Sustainability-Framework Development and Application. Sustainability 2021, 13, 1068. https://dx.doi.org/10.3390/ su13031068

Received: 28 October 2020 Accepted: 25 November 2020 Published: 21 January 2021

Publisher's Note: MDPI stays neutral with regard to jurisdictional claims in published maps and institutional affiliations.

Copyright: (c) 2021 by the authors. Licensee MDPI, Basel, Switzerland. This article is an open access article distributed under the terms and conditions of the Creative Commons Attribution (CC BY) license (https:// creativecommons.org/licenses/by/ $4.0 /)$.

\begin{abstract}
Despite previous research in the literature indicating the relationship between corporate sustainability, organizational capabilities and industrial clusters, this interconnection has not yet been satisfactorily explored and requires further investigation. Therefore, this paper proposes a theoretical framework that relates five cluster characteristics (CC) in developing seven Organizational Capabilities for Sustainability (OCS), which are identified in the literature review. To refine the theoretical framework, seven companies were inserted in a Brazilian footwear cluster. Out of the 29 proposed relationships in the theoretical framework, 16 were evidenced and they generated our research propositions. This study primarily expands the literature by providing theoretical and empirical evidence for the role that clusters can have in enabling companies to develop OCS and in turn improve their corporate sustainability.
\end{abstract}

Keywords: corporate sustainability; organizational capabilities for sustainability; clusters; capabilities

\section{Introduction}

The necessity for organizations to take environmental and social issues into account when seeking higher economic performance is debated broadly in the literature [1-4]. Given this context, corporate sustainability is gaining increased prominence among managers and researchers.

Hart [5] signaled that sustainability challenges would be paramount for companies developing organizational resources and capabilities. Following Hart's research, several authors began relating the development of specific company capabilities with sustainability [6-9] revealing that this line of thinking has gained strength over the years. Annunziata, Pucci, Frey and Zanni [10] argue that sustainability-oriented companies must identify and develop specific capabilities rooted in their organization to implement practices that create competition in a market that is increasingly aware of sustainability.

Although a body of knowledge about organizational capabilities for sustainability exists, authors have recently discussed the need for increased research in this area [1,2,11-14]. Organizational capabilities for sustainability (OCS) literature has predominantly focused on individual companies thus far [1], neglecting the moderating role of companies' environmental characteristics and their interrelationships when they implement sustainable initiatives [15]. Galdeano-Gómez, Céspedes-Lorente and Martínez-del-Río [15] signal that findings on the external effects on companies that achieve competitive advantages based on their environmental capabilities have important implications for future research both in the field of environmental management strategy and in studies on interorganizational networks, such as industrial clusters.

In interorganizational network studies, much of the OCS research has focused on supply chain type networks [16-19]. In examining industrial clusters, because so few studies have addressed OCS, only three studies can be cited. For example, Hilliard and 
Jacobson [20] explored whether companies in clusters could improve environmental performance by developing cleaner technologies in response to imposed regulations. They concluded that companies located in a cluster were more likely to comply with regulatory standards and possess dynamic capabilities to enhance problem solving abilities and acquire current knowledge concerning environmental issues. However, they did not ultimately find that companies located in the cluster were more likely to develop such dynamic capabilities. The authors justified this result by stating that despite geographical proximity, the studied cluster still did not exhibit strong interaction between companies.

Perez-Aleman [21] analyzed two regulatory processes (related to environmental sustainability and food safety) through a qualitative study of two clusters. The analysis showed clusters' critical role in regulatory processes since interactions at the local level helped promote understanding, interpretation and implementation of changes.

Finally, Martínez-del-Río and Céspedes-Lorente [22] integrated cluster characteristics with environmental issues to develop a model of the motivations for adopting environmental responsiveness in clusters. The authors highlighted the role of cluster mechanisms as drivers of environmental responsiveness. However, this study was limited to analyzing a specific type of capability, that is, the environmental response capability. This study presented an opportunity for further analysis on different capabilities in the same context.

To expand the research on different capabilities, Bezerra et al. [1] highlight the importance of developing research on OCS in different productive arrangements, such as industrial clusters. Clusters can be defined as a geographical concentration of related companies, institutions and other entities, which facilitate cooperation and competition [23]. Faustino, Gohr and Santos [24] found that clusters facilitate resource and capability sharing between companies.

Industrial clusters are recognized for playing a critical role in market competitiveness and economic development $[23,25]$. In addition to improving performance, the literature has shown that industrial clusters can also further corporate sustainability [21,22,26-28]. However, studies exploring the role clusters play in corporate sustainability are still scarce [29-31].

Thus, motivated by the relationships suggested between these research themes (corporate sustainability, organizational capabilities and industrial clusters) and seeking to fill gaps in the literature, the following research question emerges: How can industrial clusters foster the development of organizational capabilities for sustainability (OCS)? Hence, this paper proposes a theoretical framework that shows cluster characteristics' relationships in developing OCS. The literature does not present a direct method for how cluster characteristics promote OCS development. Therefore, the expected benefits of these characteristics were identified and these benefits were in turn connected with organizational capabilities for sustainability. These connections were then represented in the proposed framework. To refine the proposed framework, we conducted case studies in seven companies located in a footwear cluster in Brazil.

Thus, this research contributes to studies and business practices on industrial clusters, organizational capabilities and corporate sustainability. The proposed framework provides a theoretical background and explores empirical evidence about how cluster characteristics, which can generate benefits for companies located in clusters, contribute to developing capabilities to improve companies' sustainability.

Although the trade-off between economic growth and sustainability is inevitable, it is still relevant to study relationships between clusters and organizational capabilities and sustainability, since synergies and interdependencies exist between cluster development and sustainability [32]. We explore these synergies.

The article is structured as follows: following this introduction, Section 2 includes a literature review of cluster characteristics and OCS. From these constructs, Section 3 proposes the theoretical framework. Section 4 describes the material and methods, which applies and refines the framework using case studies. Section 5 presents results, followed by the 
discussion in Section 6. Finally, Section 7 presents the studies' conclusions, contributions, limitations and opportunities for further research.

\section{Industrial Clusters and Organizational Capabilities for Sustainability}

Industrial agglomerations, treated under the name of industrial clusters, gained popularity from Porter's 1990 and 1998 works, which argued that clusters played a critical role in competitiveness and economic development, as they brought a series of benefits to companies located in them, such as competitive advantage and better performance [24,33-36].

The relational view (RV) who consider that resources and capabilities can exceed the limits of companies and can be incorporated into inter-firm routines and processes and can be sources of competitive advantage [37]. Lavie [38] extended the resourcebased view (RBV) by revealing that companies interconnected in networks can exploit external resources and capabilities embedded in the alliance network and provide strategic opportunities for companies. In this sense, it is understood that companies located in industrial clusters may have their organizational capabilities strengthened, as these are influenced by the context in which they operate and by the interorganizational collaboration provided by this organizational arrangement.

Many authors are studying this phenomenon. For example, Hervas-Oliver, et al. [39] by adopting bibliometric methods to analyze the cluster literature verified that many articles on industrial clusters were concerned with managerial capabilities and absorptive capacity [40]. They focused on topics about innovation and the use of a managerial approach by which the core units of analysis were cluster firms and their strategies and capabilities to use and exploit external knowledge in order to be innovative.

Hilliard and Jacobson [20] highlighted that geographical proximity and firm-specific features determine the ability of cluster firms to respond to new challenges, such those regarding environmental ones, focusing on firms' ability to implement cleaner technology. Recently, Oliveira and Silva [41] showed how interorganizational learning and dynamic management capabilities could improve cluster performance; however, not focusing on environmental and social performance.

Almeida, et al. [42], through a systematic literature review, also demonstrated that the development of collaborative (or relational) capabilities in different business network, such as industrial clusters, could influence the adoption of sustainable strategies (especially those proposed by the natural resource-based view $[5,43]$.

However, the authors have not studied the benefits that such capabilities could bring to companies inserted in industrial clusters. Thus, there is evidence that industrial clusters influence the development of organizational capabilities and that capabilities increase cluster performance. Organizational capabilities can be defined as skills and routines that allow organizations to perform tasks, using their base of available resources to achieve desired results $[44,45]$.

More recently, industrial clusters had been linked to sustainability (social, environmental and economic issues) and the benefits that companies located in clusters can have on sustainability have been identified [26-28]. However, the literature is still relatively incipient when associating clusters to the development of organizational capabilities with a focus on sustainability.

Since this study seeks to cover this research gap, a thorough literature analysis was developed, both focused on classic and general research on industrial clusters and studies about clusters in the context of sustainability. Therefore, it was possible to identify five aspects that characterize a cluster. These five characteristics are: Geographical proximity of companies (CC1); Local level interactions and collaboration; formal and informal associations and networks (CC2); Associations/interactions with support institutions (public and private companies) (CC3); Competition stimulus (CC4); and Identity / sociocultural factors (CC5). Table 1 associates these characteristics with their benefits, which are detailed in the literature. 
Table 1. Cluster characteristics and their potential associated benefits.

\begin{tabular}{|c|c|c|c|c|c|c|}
\hline \multicolumn{5}{|c|}{ Cluster Characteristics } & \multirow{2}{*}{ Possible Benefits } & \multirow{2}{*}{ Authors } \\
\hline CC1 & $\mathrm{CC} 2$ & $\mathrm{CC} 3$ & CC4 & CC5 & & \\
\hline$\bullet$ & $\bullet$ & $\bullet$ & & $\bullet$ & $\begin{array}{l}\text { B1: Information and knowledge } \\
\text { sharing; knowledge spillovers; } \\
\text { learning; experiences; absorption } \\
\text { of knowledge; know-how. }\end{array}$ & {$[7,15,21-23,25-28,46-52]$} \\
\hline$\bullet$ & $\bullet$ & $\bullet$ & & & $\begin{array}{l}\text { B2: Collective action to address } \\
\text { challenges; sharing solutions; } \\
\text { joint management of shared } \\
\text { equipment and services. }\end{array}$ & {$[21,27-29,49,52]$} \\
\hline$\bullet$ & $\bullet$ & $\bullet$ & $\bullet$ & $\bullet$ & $\begin{array}{l}\text { B3: Support for innovation; } \\
\text { technology; continuous } \\
\text { innovation; creativity. }\end{array}$ & {$[21,23,25-29,47-50]$} \\
\hline$\bullet$ & & $\bullet$ & $\bullet$ & & $\begin{array}{l}\text { B4: Reputation; improvement in } \\
\text { marketing; customer attraction; } \\
\text { better communication. }\end{array}$ & {$[15,22,23,27,50,52]$} \\
\hline$\bullet$ & & & & & $\begin{array}{l}\text { B5: Access to intensive/qualified } \\
\text { labor, specialized suppliers; flow } \\
\text { of employees. }\end{array}$ & {$[15,23,29,49,50,52]$} \\
\hline$\bullet$ & $\bullet$ & $\bullet$ & $\bullet$ & $\bullet$ & $\begin{array}{l}\text { B6: Flexibility to act quickly; } \\
\text { responsiveness of companies; } \\
\text { responsiveness to market } \\
\text { changes/adaptation. }\end{array}$ & {$[21-23,26,29,49,52]$} \\
\hline \multirow[t]{3}{*}{$\bullet$} & $\bullet$ & $\bullet$ & $\bullet$ & & $\begin{array}{l}\text { B7: Facilitate the flow of } \\
\text { resources; improve products and } \\
\text { processes; short-term/fast } \\
\text { operations; specialized services; } \\
\text { reduced transaction costs; } \\
\text { process efficiencies. }\end{array}$ & {$[21,22,25,27,29,49,52]$} \\
\hline & $\bullet$ & $\bullet$ & $\bullet$ & & $\begin{array}{l}\text { B8: Training programs; } \\
\text { infrastructure; shared vision to } \\
\text { face challenges; training; } \\
\text { motivation. }\end{array}$ & {$[21-23,28,49]$} \\
\hline & & & & $\bullet$ & B9: Trust. & [28] \\
\hline
\end{tabular}

The literature agrees that developing organizational capabilities can significantly influence company sustainability and different types of organizational capabilities for sustainability (OCS) have been studied $[1,7,9,17,53]$. One recent study based on a systematic literature review compiles academic knowledge of OCS and identifies seven OCS categories [1]. These categories are (1) capabilities related to collaborative relationships for sustainability (OCS1), (2) capabilities related to the absorption of knowledge/learning about sustainability (OCS2), (3) capabilities related to innovation/technology for sustainability (OCS3), (4) capabilities related to alignment/motivation for sustainability (OCS4), (5) capabilities related to marketing/external communication for sustainability (OCS5), (6) capabilities related to flexibility /adaptation of sustainable issues (OCS6) and (7) capabilities related to managing sustainable operations (OCS7).

\section{The Proposed Theoretical Framework: Relating Cluster Characteristics to the Development of Organizational Capabilities for Sustainability}

The five cluster characteristics mentioned in Section 2 were related to the OCS found in Bezerra, et al. [1]. This study explores which of these characteristics influence OCS development. The form of association developed in this research is through the perception of benefits arising from the cluster characteristics that mediate this relationship with the OCSs. 
In this context, the geographical proximity of companies is used as an example. This cluster characteristic can facilitate information and knowledge sharing; knowledge spillovers; learning; experiences; absorption of knowledge and know-how (see "B1" in Table 2). Therefore, this characteristic can influence the development of capabilities related to the absorption of knowledge/learning about sustainability capabilities because it is linked to the absorption of knowledge and learning for sustainability (OCS2).

Based on this rationale, a theoretical framework is proposed, linking cluster characteristics (CC) and organizational capabilities for sustainability (OCS). Figure 1 presents this theoretical framework, which visualizes the relationships between CC and the OCS identified in the literature.

Table 2. Case study company characteristics.

\begin{tabular}{cccccccc}
\hline \multirow{2}{*}{$\begin{array}{c}\text { Characteristics } \\
\text { of Companies }\end{array}$} & A & B & C & D & E & F & G \\
\hline & Founding year & 1994 & 2000 & 2006 & 1978 & 2006 & 1998 \\
\hline $\begin{array}{c}\text { Number of } \\
\text { employees }\end{array}$ & 59 & 10 & 29 & 8000 & 32 & 15 & 2005 \\
\hline Company size & Small & Micro & Small & Large & Small & Micro & Micro \\
\hline Main products & $\begin{array}{c}\text { Line of } \\
\text { men's } \\
\text { footwear }\end{array}$ & $\begin{array}{c}\text { Line of } \\
\text { women's } \\
\text { footwear }\end{array}$ & $\begin{array}{c}\text { Slippers; Personalized } \\
\text { slippers Sandals; Soles }\end{array}$ & $\begin{array}{c}\text { Footwear } \\
\text { and sporting } \\
\text { goods }\end{array}$ & $\begin{array}{c}\text { Children's } \\
\text { footwear }\end{array}$ & $\begin{array}{c}\text { Men's } \\
\text { fotwear and } \\
\text { sports } \\
\text { equipment }\end{array}$ & $\begin{array}{c}\text { Women's } \\
\text { footwear, } \\
\text { bags and } \\
\text { accessories }\end{array}$ \\
\hline
\end{tabular}

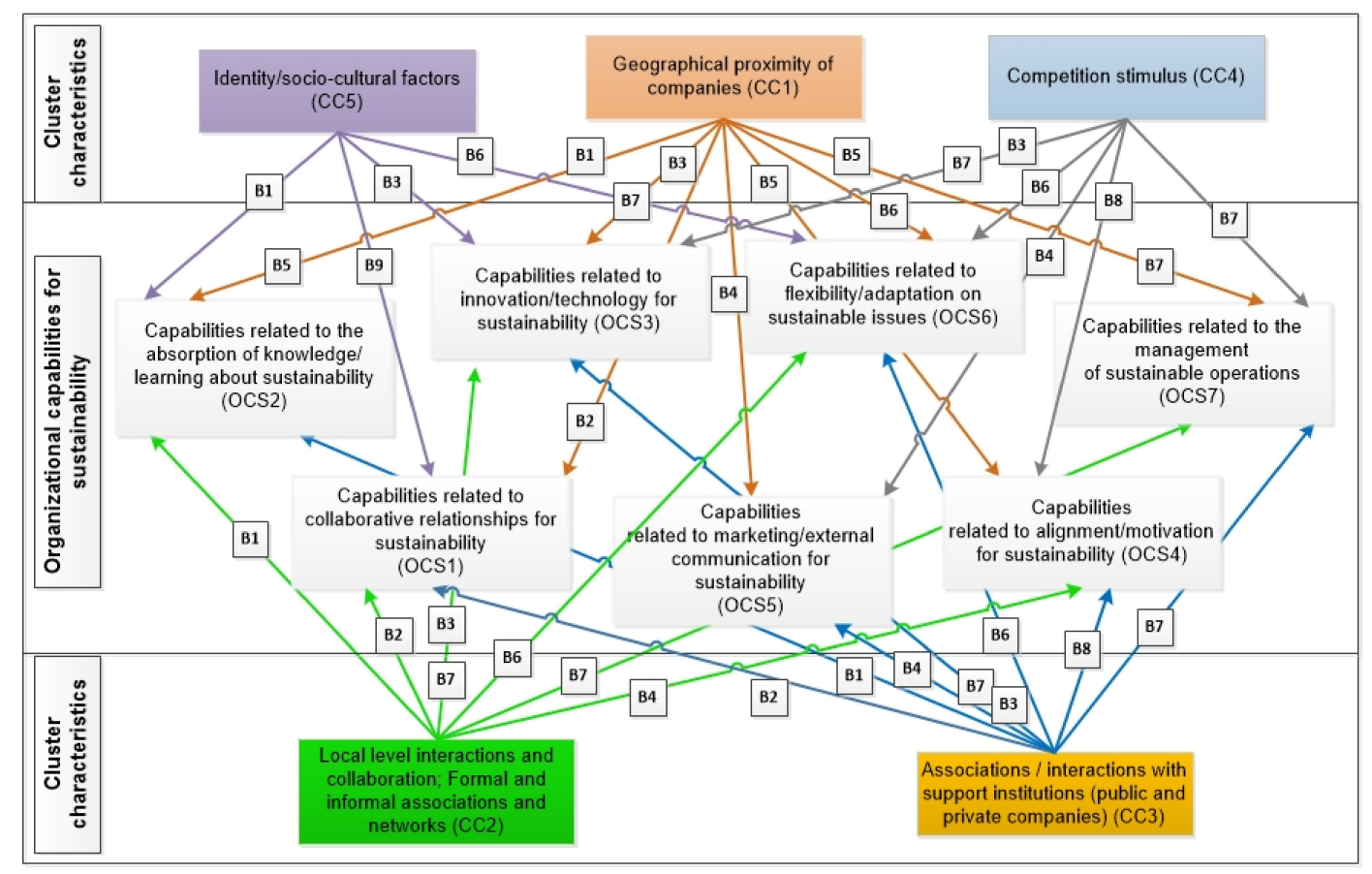

Figure 1. Theoretical framework linking cluster characteristics and organizational capabilities for sustainability. Note: B1: Information and knowledge sharing; knowledge spillovers; learning; experiences; absorption of knowledge; know-how; B2: Collective action to address the challenges; sharing solutions; joint management of shared equipment and services; B3: Support for innovation; technology; continuous innovation; creativity; B4: Reputation; improvement in marketing; Customer attraction; Better communication; B5: Access to intensive/qualified labor, specialized suppliers; flow of employees; B6: Flexibility to act quickly; Responsiveness of companies; respond to market changes/adaptation; B7: Facilitate the flow of resources; improve products and processes; Short-term/fast operations; specialized services; reduced transaction costs; process efficiencies; B8: Training programs; infrastructure; shared vision to face challenges; training; motivation; B9: Trust. 


\section{Materials and Methods}

To answer our research question, we proposed a theoretical framework that relates cluster characteristics and OCS development. To refine it, we applied a case study as our primary research method, from which we generated research propositions. Using a case study is appropriate in the early stages of research on a topic, thereafter, information derived from an in-depth empirical investigation [54] is desirable in developing a theory or theme [55].

This research performs multiple case studies in seven companies operating in a footwear cluster situated in Brazil (as explained below). According to Eisenhardt and Graebner [56], multiple case studies create a more robust theory, which more precisely delineates constructs and allows propositions to be developed based on varied empirical evidence.

\subsection{Case Selection}

In order to select a cluster, we used the following criteria: (i) to be an economically representative cluster for the State and Brazil; and, (ii) having companies that adopted initiatives focused on sustainability. Thus, we contacted the state nucleus coordinator for supporting clusters and Sebrae (Brazilian Support Service for Micro and Small Enterprises), which is an organization that maps clusters in each of Brazil's states. Thus, we selected the footwear cluster located in the Northeast of Brazil that is part of the PROMOS project, which attempts to implement the Italian industrial district model in Brazilian clusters [57].

The footwear sector has relevant economic and social importance for the country, accounting for $4 \%$ of the GDP of the Brazilian Manufacturing Industry. Brazil was the fourth-largest producer of footwear in the world in 2019 [58]. In numbers, the country's footwear sector generates more than 270 thousand direct jobs, produced 944 million pairs of shoes in 2018 and exported 115 billion pairs of shoes in 2019 [58]. Among businesses in the country that produce the most significant amounts of footwear, the cluster where the companies are inserted is the second-largest producer of footwear in its region [59].

Given how this sector is representative of the country's larger economy, studies that include socio-environmental sustainability in footwear production are crucial. Footwear production can create a distressing amount of waste materials, such as plastic, rubber, synthetic material, leather and textile, among others.

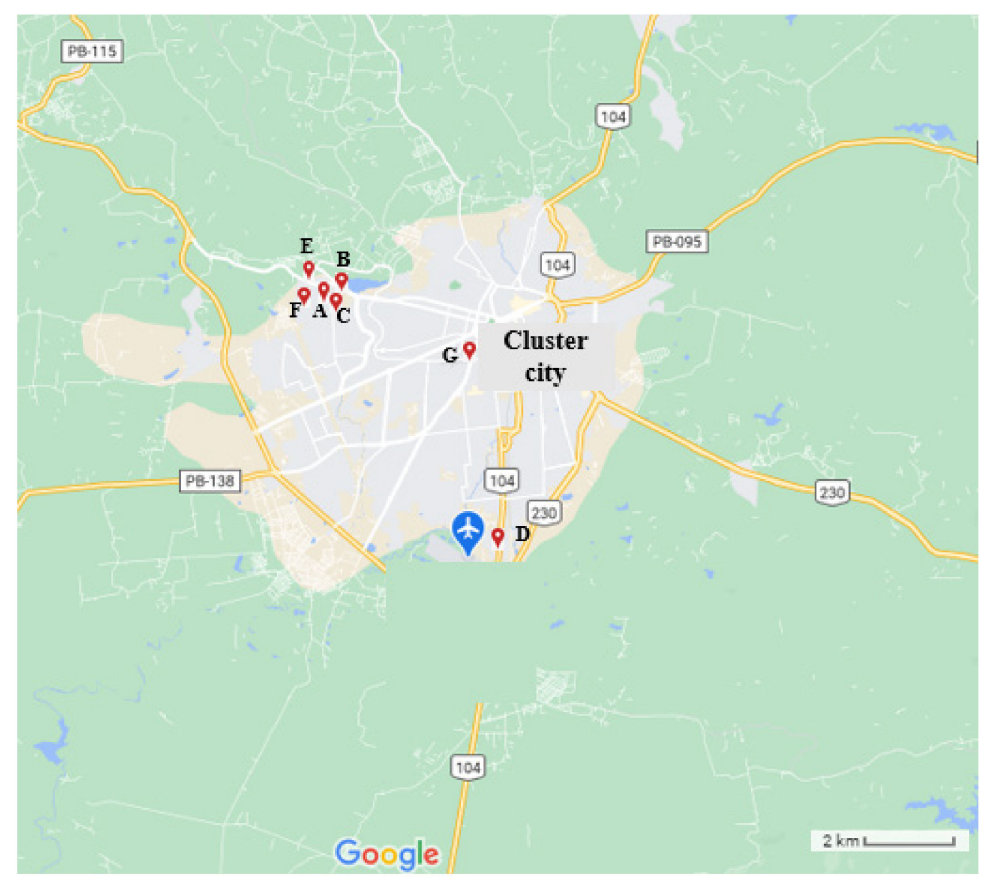

Figure 2. Location of companies in the cluster. 
The companies' selection criteria were that they displayed actions linked to environmental and/or social sustainability. Again, we contacted the state nucleus coordinator for supporting clusters and Sebrae and they directed the most suitable companies for the study. Seven companies, featuring multiple case studies, were selected for our research since we expected this size group to have a higher degree of consistency in its results [54]. Table 2 details a summary of company information. The size of the companies was defined based on the classification of the Brazilian Institute of Geography and Statistics - IBGE. Figure 2 provides a map with the locations of the companies studied, which allows a better picture of the cluster and how these companies fit in.

\subsection{Data Collection and Analysis}

We primarily used semi-structured interviews to collect data [54] and unsystematic observation (carried out during interviews) as well as cluster documents and records. We selected interviewees if they were managers or worked directly in sustainability management or decision-making.

Prior to data collection, we developed a research protocol to guide researchers in data collection [54]. A semi structured interview script was also developed based on the proposed framework (Figure 1). We used a pilot test to refine this script, which a researcher who specializes in cluster and corporate sustainability conducted. We conducted this pilot test to improve the script and make it easier for managers to understand it.

The interview script was divided into two main stages. In the first stage, questions addressed the company's OCS. In the second stage, the questions concerned CC in order to identify which of the OCS and CC fit in the studied cluster's context. In this stage, candidates were encouraged to think not only about their company individually but also about the cluster as a whole, specifically how the companies within the cluster interact with one another. When asking about each CC, we sought to relate it to its respective OCS.

The interviews occurred between the months of October and November 2018. All interviews were fully recorded, transcribed and coded. The interviews were coded and analyzed in a multiple case study database, using Atlas.ti 6.0 software, GmbH, Berlin, Germany. The codes created in the software refer to the constructs that form the research framework. Each code was assigned to a data segment from the transcribed interviews in order to discover patterns and relationships between the interviewees' responses concerning OCS and CC as well as to make associations between codes. Initially, cross-case analysis was performed for CC. Then, within-case analysis and cross-case analysis were performed for OCS.

Finally, OCS and CC findings are compared with one other in order to identify which relationships in the proposed framework occur in the empirical context we analyzed. At this point, literature review findings are also compared with empirical study results. This analysis allowed us to generate research proposals and refine the theoretical framework initially proposed. To ensure information accuracy, we developed a technical report, which we sent to the companies participating in the study.

\section{Results}

\subsection{Footwear Cluster Description}

The footwear cluster in this study is located in northeastern Brazil. It originated from livestock activities in the Region, mainly cotton. From the 1940 s on, tannery activities appeared, initially intended for making saddles for riding. However, the existence of a cattle, sheep and goat herd in the region and tannery activities created the preconditions for the production of shoes and the like leather [60].

Brazil consolidated itself as an important shoe supplier for the world market in the 1970s when the product acquired relevance in the national export basket. At that time, large Brazilian footwear companies were located mainly in the south and southeast of the country.

However, in the 1990s, changes occurred in the production conditions and the competition pattern of the international market, caused severe difficulties for the Brazilian 
industry, which had specialized in the production of low-cost shoes and was unable to compete $[61,62]$. In this sense, shoe production in Brazil began to move to the northeast of the country, stimulated by lower costs, government incentives and the favorable position of the region concerning the main external consumer markets [61-63].

The footwear cluster in this study is among the main footwear hubs in the country [59]. There is a historical vocation in the city where the cluster for the production of shoes is located, where a large number of shoemakers and informal producers are located, most companies are characterized by family learning and experience passed from father to son [60].

\subsection{Cluster Characteristics and OCS Analysis}

The five cluster characteristics from the literature (Table 1) were evidenced in the studied cluster. However, their degrees of presence were assessed at different levels, which Table 3 shows.

Table 3. Degrees of presence of footwear cluster characteristics analyzed.

\begin{tabular}{lc}
\hline \multicolumn{1}{c}{ Characteristics of Clusters } & Importance in the Cluster \\
\hline CC1: Geographical proximity of companies & $\mathrm{ST}$ \\
\hline $\begin{array}{l}\text { CC2: Local level interactions and collaboration; } \\
\text { formal and informal associations and networks }\end{array}$ & $\mathrm{ST}$ \\
\hline $\begin{array}{l}\text { CC3: Associations/interactions with support } \\
\text { institutions (public and private companies) }\end{array}$ & $\mathrm{ST}$ \\
\hline CC4: Competition stimulus & $\mathrm{MO}$ \\
\hline CC5: Identity/sociocultural factors & $\mathrm{ST}$ \\
\hline ST: Strong characteristic MO: Moderate characteristic WE: Weak characteristic analysis.
\end{tabular}

All companies are relatively close to each other (CC1), which facilitates interaction and collaboration (CC2). Five of the companies are located in an industrial pole, where interaction is even more robust due to greater proximity. The remaining companies are located in nearby neighborhoods.

The presence of important institutional actors-such as S System-are also worth noting in the cluster development process (CC3). The $\mathrm{S}$ system is a set of corporate institutions focused on professional training, research and technical and social assistance. It includes the leather and footwear school, the Federal University, Fiep (Federation of Industries of the State of Paraíba) as well as other educational, technological and research institutions. All seven companies agree that these institutions hold great value for the cluster.

We also verified that moderate competition exists between the companies we studied, since they do not compete in the same market due to segmentation of product lines and a diversified set of target customers (CC4). Finally, the cluster has a robust historical and cultural identity for the region into which it is inserted (CC5).

Appendix A presents a detailed table with descriptions of the degree to which each characteristic was evaluated, followed by detailed evidence from the case studies that determined each evaluation. This evidence was corroborated by most of the companies studied, which demonstrates a consensus among companies about the specificities and the functioning of the cluster in which they are inserted.

The seven OCS were also analyzed and evaluated according to their degree of presence in the companies studied (Table 4). Appendix A includes the detailed empirical evidence.

In the companies we examined, we verified that most OCS occur moderately. This finding is supported by the fact that if companies have measures that impact sustainability, these measures often indirectly correlate with corporate strategies aimed at improving overall performance. On the other hand, OCS5 (capabilities related to marketing/external communication for sustainability) is considered nonexistent in most companies because they do not exhibit sustainability-oriented marketing strategies, such as socially responsible products, brands linked to sustainability and so forth. 
Table 4. Summary of studied companies' Organizational Capabilities for Sustainability (OCS).

\begin{tabular}{cccccccc}
\hline \multirow{2}{*}{ Companies } & \multicolumn{7}{c}{ Organizational Capabilities for Sustainability } \\
\cline { 2 - 8 } & OCS1 & OCS2 & OCS3 & OCS4 & OCS5 & OCS6 & OCS7 \\
\hline A & MO & MO & MO & WE & NO & MO & MO \\
\hline B & MO & MO & WE & MO & NO & MO & WE \\
\hline C & MO & MO & MO & WE & NO & MO & MO \\
\hline D & ST & ST & ST & MO & MO & ST & ST \\
\hline E & MO & MO & MO & MO & NO & MO & MO \\
\hline F & MO & MO & MO & MO & NO & MO & MO \\
\hline G & MO & MO & MO & WE & NO & MO & WE \\
\hline
\end{tabular}

ST: Strong capability MO: Moderate capability WE: Weak capability NO: Nonexistent capability; OCS1: capabilities related to collaborative relationships for sustainability; OCS2: capabilities related to the absorption of knowledge/learning about sustainability; OCS3: capabilities related to innovation/technology for sustainability; OCS4: capabilities related to alignment/motivation for sustainability; OCS5: capabilities related to marketing/external communication for sustainability; OCS6: capabilities related to flexibility/adaptation of sustainable issues; OCS7: capabilities related to managing sustainable operations.

The OCS in most companies we studied (A, B, C, E, F and G) show similar degrees of development. This finding may be because they are inserted in an industrial cluster, which allows them each to receive the same support from government and supporting institutions; negotiate with the same suppliers and customers; and interact with one another since they are in close proximity [23].

We should note that Company D is the only company with higher OCS levels. This is because Company $\mathrm{D}$ is the only large company and as a result, it has different characteristics from the other companies, such as its ability to negotiate with different suppliers and customers, it possessing increased government support and so forth.

\subsection{Relationships between Cluster Characteristics and OCS}

Once the cluster characteristics and the OCS of the companies we studied were identified, this information was crossed in order to explore relationships in the proposed framework (Figure 1). Tables $5-8$ below summarize the relationships found; each table is dedicated to a cluster characteristic. Column 2 of each table shows the benefits that mediated these relationships and Column 3 shows empirical evidence for each characteristic. Column 4 presents theoretical evidence corroborating these findings. Finally, Column 5 shares the propositions generated from the empirical and theoretical evidence.

No proposition is developed for OCS5 (capabilities related to marketing/external communication for sustainability) because the empirical evidence was only verified for Company D, which received competitive pressure related to green marketing mainly by companies outside the cluster and not within it. Finally, although the literature asserts that CC5 (identity/sociocultural factors) influences the generation of several benefits (B1, B3, B6 and B9) and that they may be linked to developing OCS, the empirical data did not support this conclusion. 
Table 5. Relationships between CC1 (geographical proximity of companies) and OCS.

\begin{tabular}{|c|c|c|c|c|}
\hline Related OCS & Linked Benefit & Empirical Evidence & Theoretical Evidence & Propositions \\
\hline OCS1 & B2 & $\begin{array}{l}\text { Facilitating joint meetings and } \\
\text { training to address issues related } \\
\text { to sustainability (e.g., } \\
\text { developing more sustainable } \\
\text { products and processes, waste } \\
\text { reduction, process optimization, } \\
\text { correct disposal of inputs, } \\
\text { worker safety, environmental } \\
\text { standards, etc.) (companies A, B, } \\
\text { C, E, F and G). }\end{array}$ & $\begin{array}{l}\text { The collective action strongly } \\
\text { present in clusters can provide } \\
\text { companies with a clearer path } \\
\text { to sustainability, since } \\
\text { collaboration is seen as a } \\
\text { crucial means for solving } \\
\text { sustainability challenges } \\
{[26,64-66]}\end{array}$ & $\begin{array}{l}\text { (P1a): CC1 is related to } \\
\text { developing capabilities } \\
\text { in collaborative } \\
\text { relationships for } \\
\text { sustainability (OCS1). }\end{array}$ \\
\hline
\end{tabular}

Facilitating meetings between companies allows the exchange and absorption of sustainable information (companies A, B, C,

B1

E and F). (e.g., supplier information for purchasing recycled material and products

OCS2 that have less of an impact on workers' health, etc.).

Specialized suppliers offer lectures and produce more B5 sustainable products (e.g., solar energy, water-based glue) (A, B, C, E and G).

OCS6 B6 Jointly issued environmental licenses (companies A, B, C, E and $\mathrm{F}$ ).
Proximity allows for the exchange of information and knowledge that enrich the local context and simultaneously encourage workers to share information [28].

Proximity is a means of more easily obtaining suppliers and service providers as they try to penetrate more aggressively in a concentrated market due to efficiency gains in productivity and marketing [23,29,52].

Business proximity can make it easier to more quickly implement necessary changes [23]. Companies in a cluster face the same environmental problems, so they can develop and share solutions at the territorial level [27].

Collective action through associations can help reduce transaction costs (due to trusted relationships among companies) [25]. Economies of scale can result from joint actions and shared services as companies negotiate jointly with the same suppliers, increasing companies' bargaining power [27].
(P1b): The CC1 is related to developing capabilities in knowledge absorption/learning about sustainability (OCS2).

(P1c): The CC1 is related to developing capabilities in flexibility/adaptation to sustainable issues (OCS6).
Input loans between companies (A, B, C, E, F and G). Purchase policies and sale of inputs between some companies in the OCS7 B7 cluster (Companies E and F) and joint purchases (companies A, E, $F$ and $G$ ). Policies that reduce carrier wait times or companies' displacement from suppliers and impact the reduction of fossil fuel emissions.
(P1d): The CC1 is related to developing capabilities in managing sustainable operations (OCS7).

\footnotetext{
OCS1: capabilities related to collaborative relationships for sustainability; OCS2: capabilities related to the absorption of knowledge/learning about sustainability; OCS6: capabilities related to flexibility/adaptation of sustainable issues; OCS7: capabilities related to managing sustainable operations. B1: Information and knowledge sharing; knowledge spillovers; learning; experiences; absorption of knowledge; know-how; B2: Collective action to address the challenges; sharing solutions; joint management of shared equipment and services; B3: Support for innovation; technology; continuous innovation; creativity; B4: Reputation; improvement in marketing; Customer attraction; Better communication; B5: Access to intensive/qualified labor, specialized suppliers; flow of employees; B6: Flexibility to act quickly; Responsiveness of companies; respond to market changes/adaptation; B7: Facilitate the flow of resources; improve products and processes; Short-term/fast operations; specialized services; reduced transaction costs; process efficiencies; B8: Training programs; infrastructure; shared vision to face challenges; training; motivation; B9: Trust.
} 
Table 6. Relationships between CC2 (local level interactions and collaboration; formal and informal associations and networks) and OCS.

\begin{tabular}{|c|c|c|c|c|}
\hline Related OCS & Linked Benefit & Empirical Evidence & Theoretical Evidence & Propositions \\
\hline OCS1 & B2 & $\begin{array}{l}\text { Interactions allow for collective } \\
\text { actions such as periodic } \\
\text { meetings, training and joint } \\
\text { lectures where topics related to } \\
\text { sustainability are addressed } \\
\text { (companies A, B, C, E, F and G). }\end{array}$ & $\begin{array}{l}\text { Companies that interact in the } \\
\text { same area and face similar } \\
\text { problems are able to jointly } \\
\text { address challenges, implement } \\
\text { changes and develop and } \\
\text { share solutions }[21,29,52] \text {. }\end{array}$ & $\begin{array}{l}\text { (P2a): CC2 is related to } \\
\text { developing capabilities } \\
\text { in collaborative } \\
\text { relationships for } \\
\text { sustainability (OCS1). }\end{array}$ \\
\hline OCS2 & B1 & $\begin{array}{l}\text { Interactions facilitate formal and } \\
\text { informal meetings between } \\
\text { companies that allow for the } \\
\text { exchange and absorption of } \\
\text { sustainable information } \\
\text { (companies A, B, C, E, F and G). }\end{array}$ & $\begin{array}{l}\text { Companies can acquire } \\
\text { knowledge and experience } \\
\text { from interactions with other } \\
\text { companies on sustainable } \\
\text { issues }[15,22] \text {. Interactions } \\
\text { between companies foster trust } \\
\text { and facilitate the flow of } \\
\text { information [23]. }\end{array}$ & $\begin{array}{l}\text { (P2b): CC2 is related to } \\
\text { developing capabilities } \\
\text { in absorbing } \\
\text { knowledge/learning } \\
\text { about sustainability } \\
\text { (OCS2). }\end{array}$ \\
\hline OCS6 & B6 & $\begin{array}{l}\text { Jointly issued environmental } \\
\text { licenses (companies A, B, C, E } \\
\text { and F) are made possible by the } \\
\text { geographical proximity and } \\
\text { strong interactions between } \\
\text { companies. }\end{array}$ & $\begin{array}{l}\text { The significant interactions } \\
\text { between companies allow } \\
\text { them to jointly overcome } \\
\text { challenges and implement } \\
\text { actions, such as meeting } \\
\text { market demands and adhering } \\
\text { to new requirements and } \\
\text { regulations [21,29,52]. }\end{array}$ & $\begin{array}{l}\text { (P2c): CC2 is related to } \\
\text { developing capabilities } \\
\text { in } \\
\text { flexibility/adaptation } \\
\text { to sustainable issues } \\
\text { (OCS6). }\end{array}$ \\
\hline OCS7 & B7 & $\begin{array}{l}\text { Policies (previously mentioned } \\
\text { in Table 6, Line 5) that reduce } \\
\text { carrier times or companies' } \\
\text { displacement from the supplier } \\
\text { and impact the reduction of } \\
\text { fossil fuel emissions. }\end{array}$ & $\begin{array}{l}\text { Interactions between } \\
\text { companies also contribute to } \\
\text { reducing transaction costs [25] } \\
\text { and providing greater } \\
\text { economies of scale [27]. }\end{array}$ & $\begin{array}{l}\text { (P2d): CC2 is related to } \\
\text { developing capabilities } \\
\text { in managing } \\
\text { sustainable operations } \\
\text { (OCS7). }\end{array}$ \\
\hline
\end{tabular}

OCS1: capabilities related to collaborative relationships for sustainability; OCS2: capabilities related to the absorption of knowledge/learning about sustainability; OCS6: capabilities related to flexibility/adaptation of sustainable issues; OCS7: capabilities related to managing sustainable operations. B1: Information and knowledge sharing; knowledge spillovers; learning; experiences; absorption of knowledge; know-how; B2: Collective action to address the challenges; sharing solutions; joint management of shared equipment and services; B3: Support for innovation; technology; continuous innovation; creativity; B4: Reputation; improvement in marketing; Customer attraction; Better communication; B5: Access to intensive/qualified labor, specialized suppliers; flow of employees; B6: Flexibility to act quickly; Responsiveness of companies; respond to market changes/adaptation; B7: Facilitate the flow of resources; improve products and processes; Short-term/fast operations; specialized services; reduced transaction costs; process efficiencies; B8: Training programs; infrastructure; shared vision to face challenges; training; motivation; B9: Trust.

Table 7. Relationships between CC3 (associations/interactions with support institutions (public and private companies) and OCS.

\begin{tabular}{|c|c|c|c|c|}
\hline Related OCS & Linked Benefit & Empirical Evidence & Theoretical Evidence & Propositions \\
\hline OCS1 & $\mathrm{B} 2$ & $\begin{array}{l}\text { Actions developed by the S System (e.g., } \\
\text { events, meetings, trainings, lectures and } \\
\text { fairs), which cover topics, including } \\
\text { sustainability (Companies A, B, C, D E, } \\
\text { F and G). During fairs, the government's } \\
\text { role was highlighted alongside Sebrae's, } \\
\text { who each provided subsidies. The } \\
\text { government also created a cluster } \\
\text { development program and financed } \\
\text { footwear pole construction, which } \\
\text { improved the proximity of companies in } \\
\text { the cluster, thereby strengthening } \\
\text { collaborative relationships. }\end{array}$ & $\begin{array}{l}\text { Collaboration of companies } \\
\text { with other actors is important } \\
\text { for sustainability, since } \\
\text { environmental issues are not } \\
\text { paramount in most companies. } \\
\text { Companies do not generally } \\
\text { have the necessary knowledge } \\
\text { and skills to achieve } \\
\text { sustainability, so they must } \\
\text { seek such skills outside their } \\
\text { domains [64]. }\end{array}$ & $\begin{array}{l}\text { (P3a): CC3 is } \\
\text { related to } \\
\text { developing } \\
\text { capabilities in } \\
\text { collaborative } \\
\text { relationships for } \\
\text { sustainability } \\
\text { (OCS1). }\end{array}$ \\
\hline
\end{tabular}


Table 7. Cont.

\begin{tabular}{|c|c|c|c|c|}
\hline Related OCS & Linked Benefit & Empirical Evidence & Theoretical Evidence & Propositions \\
\hline OCS2 & B1 & $\begin{array}{l}\text { The described actions developed by } \\
\text { System } S \text { also allow companies to } \\
\text { absorb information related to } \\
\text { sustainability. }\end{array}$ & $\begin{array}{l}\text { Collective support and } \\
\text { connections between } \\
\text { companies and public and } \\
\text { private actors lead to shared } \\
\text { know-how, which in turn } \\
\text { facilitates knowledge } \\
\text { construction [21]. }\end{array}$ & $\begin{array}{l}\text { (P3b): CC3 is } \\
\text { related to } \\
\text { developing } \\
\text { capabilities in } \\
\text { absorbing knowl- } \\
\text { edge/learning } \\
\text { about } \\
\text { sustainability } \\
\text { (OCS2). }\end{array}$ \\
\hline
\end{tabular}

Lectures, courses and training developed by System S institutions with a focus on sustainability are aimed at both managers and employees of companies to raise all OCS4 B8 employees' environmental/social awareness, qualifications and motivation. The leather and footwear school develop labor that is working or will be working in cluster companies (Companies A, B, C, D, E, F and $G)$.

System S support helps companies to adapt and implement changes, such as meeting environmental/social regulations; providing lectures by suppliers that present environmentally responsible products; and facilitating programs aimed at promoting and preserving employee health, such as PPRA (Environmental Risk Prevention Program) and PCMSO (Occupational Health Medical Control Program) (Companies A, C, F and G).

S system institutional trainings focus on productivity, use of raw materials, labor and personnel training. The leather and footwear school provide services to cluster companies, focusing on developing new footwear models, using new processes and technologies,
Lectures and training developed by institutions that (P3d): CC3 is support clusters [23,28], complement existing employee knowledge [67]. Employee knowledge is important, since employees play a crucial role in the company's ability to achieve sustainability goals $[7,17,64,68]$.

related to developing capabilities in alignment/motivation for sustainability (OCS4).
Significantly, interactions between companies and support institutions jointly address challenges and implementing actions, such as market demands, new requirements and regulations $[21,29,52]$.

(P3e): CC3 is related to the development of capabilities in flexibility/adaptation on sustainable issues (OCS6).
Technological innovations that aim at efficiencies in production, delivery, cost reduction, resource integration and those that affect companies' sustainability may result from collaborative partnerships, involving both central companies and public-private partnerships, such as Research Institutes [28]. Relationships with other entities within the cluster help companies learn about technology [23].

\section{(P3c): $\mathrm{CC} 3$ is}

related to developing capabilities in innovation/technology for sustainability (OCS3).

(P3f): $\mathrm{CC} 3$ is

related

developing capabilities in the management of sustainable operations (OCS7).

OCS1: capabilities related to collaborative relationships for sustainability; OCS2: capabilities related to the absorption of knowledge/learning about sustainability; OCS3: capabilities related to innovation/technology for sustainability; OCS4: capabilities related to alignment/motivation for sustainability; OCS7: capabilities related to managing sustainable operations. B1: Information and knowledge sharing; knowledge spillovers; learning; experiences; absorption of knowledge; know-how; B2: Collective action to address the challenges; sharing solutions; joint management of shared equipment and services; B3: Support for innovation; technology; continuous innovation; creativity; B4: Reputation; improvement in marketing; Customer attraction; Better communication; B5: Access to intensive/qualified labor, specialized suppliers; flow of employees; B6: Flexibility to act quickly; Responsiveness of companies; respond to market changes/adaptation; B7: Facilitate the flow of resources; improve products and processes; Short-term/fast operations; specialized services; reduced transaction costs; process efficiencies; B8: Training programs; infrastructure; shared vision to face challenges; training; motivation; B9: Trust. 
Table 8. Relationships between CC4 (competition stimulus) and OCS.

\begin{tabular}{|c|c|c|c|c|}
\hline Related OCS & Linked Benefit & Empirical Evidence & Theoretical Evidence & Propositions \\
\hline OCS3; OCS7 & B3; B7 & $\begin{array}{l}\text { Actions that improve and } \\
\text { increase innovations in products } \\
\text { and processes with a focus on } \\
\text { profitability and } \\
\text { competitiveness, which } \\
\text { indirectly impact sustainable } \\
\text { issues, e.g.: } \\
\text { - } \quad \text { using recycled material as a } \\
\text { product input (A, C and E); } \\
\text { completely reusing } \\
\text { material in the production } \\
\text { process for injection } \\
\text { molding machines (waste } \\
\text { reduction) (A, C, E and F); } \\
\text { improving production } \\
\text { processes to increase } \\
\text { conformity and } \\
\text { competitiveness (e.g., } \\
\text { sustainable management of } \\
\text { solid waste, water reuse, } \\
\text { capturing solar energy for } \\
\text { parking, waste } \\
\text { transformation and } \\
\text { developing a sustainability } \\
\text { supply chain) (Company } \\
\text { D); } \\
\text { eliminating the use of } \\
\text { synthetic material in a shoe } \\
\text { model (Company C); } \\
\text { replacing leather with } \\
\text { fabric as the main input in } \\
\text { shoe, bag and accessory } \\
\text { production; } \\
\text { developing a line of colored } \\
\text { cotton products in } \\
\text { association with a local } \\
\text { cooperative (Company G). }\end{array}$ & $\begin{array}{l}\text { Rivalry plays an essential role in } \\
\text { clusters, as companies seek to } \\
\text { generate resources in order to } \\
\text { outperform competitors [22,23]. } \\
\text { Increased performance is made } \\
\text { easier as clusters also allow } \\
\text { companies to compare their } \\
\text { rivals' performance to their own } \\
\text { [23]. Thus, companies in a } \\
\text { cluster are motivated to increase } \\
\text { their competitive capabilities } \\
\text { compared with companies not } \\
\text { integrated into a cluster [22,23]. }\end{array}$ & $\begin{array}{l}\text { (P4a): CC4 is related } \\
\text { developing } \\
\text { capabilities in innova- } \\
\text { tion/technology for } \\
\text { sustainability (OCS3). } \\
\text { (P4b): CC4 is related } \\
\text { developing } \\
\text { capabilities in } \\
\text { managing sustainable } \\
\text { operations (OCS7). }\end{array}$ \\
\hline OCS5 & B4 & $\begin{array}{l}\text { Company D develops collections } \\
\text { related to sustainability, treating } \\
\text { this action as a business } \\
\text { differential. }\end{array}$ & $\begin{array}{l}\text { Companies under competitive } \\
\text { pressure are motivated to } \\
\text { develop marketing skills [22]. }\end{array}$ & $X$ \\
\hline
\end{tabular}

OCS1: capabilities related to collaborative relationships for sustainability; OCS2: capabilities related to the absorption of knowledge/learning about sustainability; OCS6: capabilities related to flexibility/adaptation of sustainable issues; OCS7: capabilities related to managing sustainable operations. B1: Information and knowledge sharing; knowledge spillovers; learning; experiences; absorption of knowledge; know-how; B2: Collective action to address the challenges; sharing solutions; joint management of shared equipment and services; B3: Support for innovation; technology; continuous innovation; creativity; B4: Reputation; improvement in marketing; Customer attraction; Better communication; B5: Access to intensive/qualified labor, specialized suppliers; flow of employees; B6: Flexibility to act quickly; Responsiveness of companies; respond to market changes/adaptation; B7: Facilitate the flow of resources; improve products and processes; Short-term/fast operations; specialized services; reduced transaction costs; process efficiencies; B8: Training programs; infrastructure; shared vision to face challenges; training; motivation; B9: Trust.

\section{Discussion}

Table 9 summarizes the relationships found between cluster characteristics and organizational capabilities for sustainability. The darker the color in the color scale, the more closely the companies align with the evidence. From the discussions presented and the propositions developed in Figure 1, the theoretical framework was refined, as shown in Figure 3. 
Table 9. Relationships identified between footwear cluster characteristics and companies' OCS.

\begin{tabular}{|c|c|c|c|c|c|c|c|}
\hline \multirow{2}{*}{$\begin{array}{c}\text { Cluster } \\
\text { Characteristics }\end{array}$} & \multicolumn{7}{|c|}{ Organizational Capabilities for Sustainability (OCS) } \\
\hline & OCS1 & OCS2 & OCS3 & OCS4 & OCS5 & OCS6 & OCS7 \\
\hline $\begin{array}{l}\text { CC1: Geographical } \\
\text { proximity of } \\
\text { companies (FO) }\end{array}$ & $\begin{array}{l}A, B, C, E, F \\
\quad \text { and } G\end{array}$ & $\begin{array}{c}\mathrm{A}, \mathrm{B}, \mathrm{C}, \mathrm{E}, \mathrm{F} \\
\text { and } \mathrm{G}\end{array}$ & & & & $\begin{array}{c}\mathrm{A}, \mathrm{B}, \mathrm{C}, \mathrm{E} \\
\text { and } \mathrm{F}\end{array}$ & $\begin{array}{l}\mathrm{A}, \mathrm{B}, \mathrm{C}, \mathrm{E}, \mathrm{F} \\
\quad \text { and } \mathrm{G}\end{array}$ \\
\hline
\end{tabular}

CC2: Local level

interactions and

collaboration;

formal and

informal

associations and

networks (FO)

$\begin{array}{cc}\text { A, B, C, E, F } & \text { A, B, C, E, F } \\ \text { and G } & \text { and G }\end{array}$
and $G$
A, B, C, E
and F

A, B, C, E, F and $\mathrm{G}$

\section{CC3: Associa-}

tions/interactions

with support institutions (public and private companies) (FO)

\begin{tabular}{|c|c|c|c|c|c|}
\hline $\begin{array}{l}\mathrm{A}, \mathrm{B}, \mathrm{C}, \mathrm{E}, \mathrm{F} \\
\text { and } \mathrm{G}\end{array}$ & $\begin{array}{c}\text { A, B, C, D, E, } \\
\text { F and G }\end{array}$ & $\mathrm{A}, \mathrm{E}$ and $\mathrm{F}$ & $\begin{array}{c}\text { A, B, C, D, E, } \\
\text { F and G }\end{array}$ & $\begin{array}{l}\text { A, C, E, } \\
\text { F and G }\end{array}$ & $\mathrm{A}, \mathrm{E}$ and $\mathrm{F}$ \\
\hline & & $\begin{array}{c}\text { A, B, C, D, E, } \\
\text { F and G }\end{array}$ & & & $\begin{array}{c}\mathrm{A}, \mathrm{B}, \mathrm{C}, \mathrm{D}, \mathrm{E}, \\
\mathrm{F} \text { and } \mathrm{G}\end{array}$ \\
\hline
\end{tabular}

CC4: Competition

stimulus (MO)

$\mathrm{F}$ and $\mathrm{G}$

$F$ and $G$

CC5: Iden-

tity/sociocultural

factors (FO)

OCS1: capabilities related to collaborative relationships for sustainability; OCS2: capabilities related to the absorption of knowledge/learning about sustainability; OCS3: capabilities related to innovation/technology for sustainability; OCS4: capabilities related to alignment/motivation for sustainability; OCS5: capabilities related to marketing/external communication for sustainability; OCS6: capabilities related to flexibility/adaptation of sustainable issues; OCS7: capabilities related to managing sustainable operations.

As displayed in Figure 3, 16 out of the 29 proposed relationships in the theoretical framework were evidenced in the empirical study. Stronger lines signal relationships that empirical findings fully corroborated. Weaker lines indicate that empirical findings partially corroborated relationships, as they were not evidenced in all companies in the case study. Finally, dashed lines show the relationships in the theoretical framework for which the empirical study did not provide evidence.

The characteristic showing the most relationships for developing OCS is CC3 (associations/interactions with support institutions, public and private companies), which has six relationships. An existing cluster development program and institutions supporting it caused this finding. CC5 (identity/sociocultural factors), despite being a strong characteristic, is the only characteristic in which it was not possible to verify relationships with OCS. This finding is due to this characteristic currently emphasizing aspects of reputation and market performance over sustainability.

However, since corporate sustainability is a worldwide trend, companies are increasingly considering needs beyond their economic, environmental and social pillars to remain competitive. In this sense, if companies in the cluster want to survive competition, sustainability could be a way to gain an edge over other companies. Because CC5 (identity/sociocultural factors) is a strong characteristic in the studied cluster, it will be an important factor in achieving greater sustainability. In general, most propositions were not evidenced in all companies in the case study as Table 9 shows.

It should be noted that only propositions $\mathrm{P} 3 \mathrm{~b}, \mathrm{P} 3 \mathrm{~d}, \mathrm{P} 4 \mathrm{a}$ and $\mathrm{P} 4 \mathrm{~b}$ are strongly based on empirical findings, since these relationships were identified in all of the companies studied. They still cannot be fully generalized, since they have been explored in a specific context. However, this does not detract from the relationships established in the other propositions, especially P1a, P1b, P1c, P2a, P2b, P2c and P3a. Such evidence was not found in Company 
$\mathrm{D}$, which besides being geographically more distant from the other studied companies, is a large company, which hinders collaborative relationships.

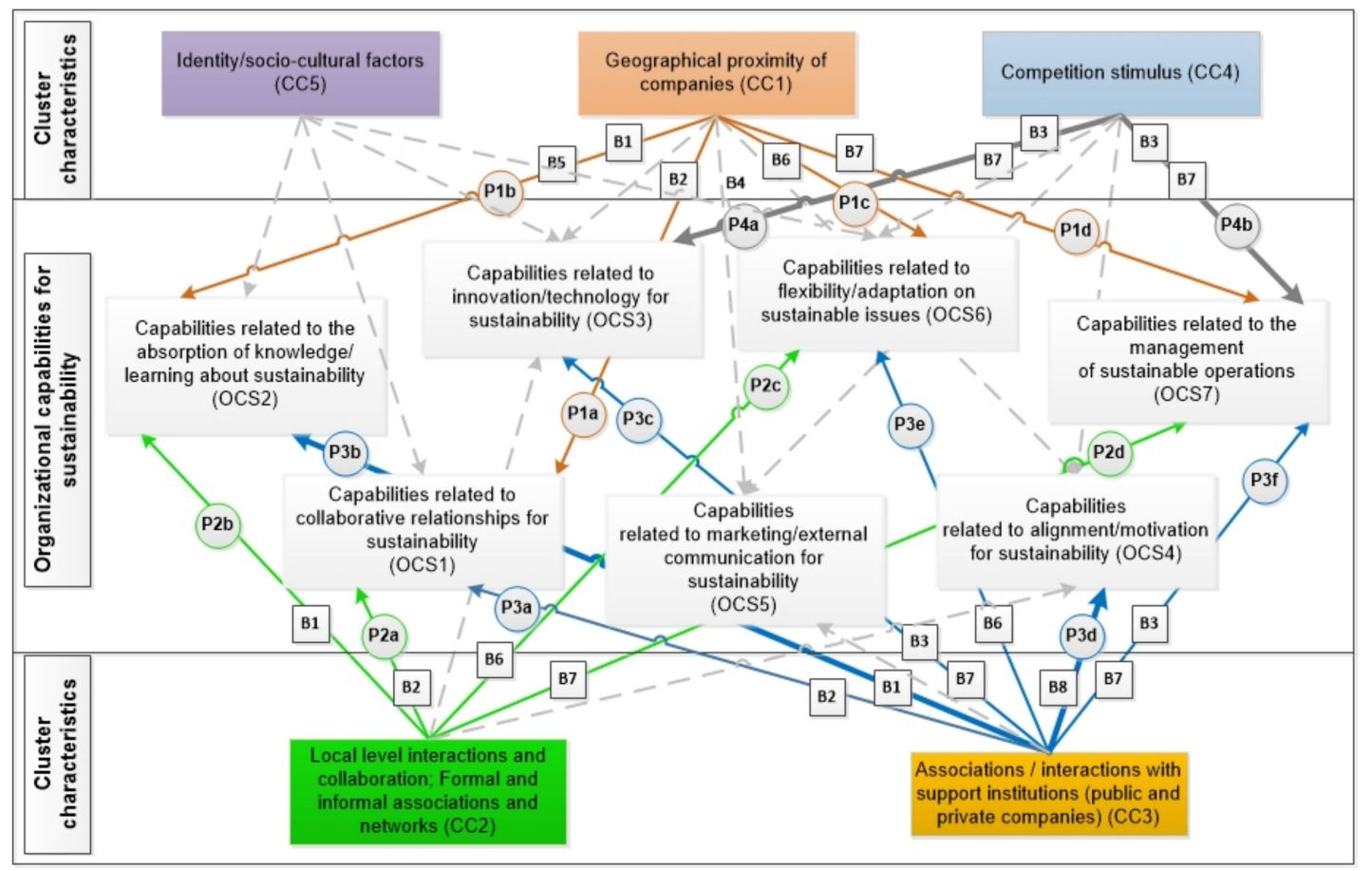

Figure 3. Refined Framework. Note: B1: Information and knowledge sharing; knowledge spillovers; learning; experiences; absorption of knowledge; know-how; B2: Collective action to address the challenges; sharing solutions; joint management of shared equipment and services; B3: Support for innovation; technology; continuous innovation; creativity; B4: Reputation; improvement in marketing; Customer attraction; Better communication; B5: Access to intensive/qualified labor, specialized suppliers; flow of employees; B6: Flexibility to act quickly; Responsiveness of companies; respond to market changes/adaptation; B7: Facilitate the flow of resources; improve products and processes; Short-term/fast operations; specialized services; reduced transaction costs; process efficiencies; B8: Training programs; infrastructure; shared vision to face challenges; training; motivation; B9: Trust.

In this sense, we can highlight the size of the company as an intervening factor in the relationship between industrial clusters and OCS, as, this may be related to the development of OCS $[69,70]$. Therefore, despite its discrepancy with the other companies, we decided to study this company in order to analyze and draw empirical conclusions that corroborate with the literature about how company size affects the constructs this research analyzes. Small and medium-sized companies that generally comply with the same laws, negotiate with the same actors (e.g., suppliers and technology providers) and face the same environment [27] will soon seek agglomeration benefits to overcome difficulties [50].

Another important factor concerning to the development of OCS in the context of clusters was the institutional regulations. As presented, companies needed to issue environmental licenses and participate in programs aimed at promoting and preserving the health of employees and the context of clusters in which they were inserted, facilitated these actions. These findings are corroborated in the literature, which argues about the critical role of clusters in enabling companies to respond to regulatory processes [20,21]. In addition, Ko and Liu [70] highlight that companies develop capabilities to overcome institutional pressures.

We also highlight the pressure from buyers and suppliers as important factors related to the development of OCS in the context of the cluster. As presented, specialized suppliers offer lectures and produce more sustainable products to the cluster companies. Besides, company $\mathrm{C}$ highlighted that it eliminated the use of synthetic material in a shoe model according to the specifications of a specific customer. Company D also highlighted that 
its main customers audit it so that it can meet the market's sustainability needs. These findings are corroborated by Lee and Klassen [71]. The authors stated that the monitoring of buyers influences the development of environmental management capabilities in the context of supply networks.

Propositions P3c and P3f require further empirical investigation, especially through case studies, to explain how and why such facts occur. Furthermore, some companies exhibit relationships between cluster characteristics and OCS, while others do not. This point is justifiable because although cluster characteristics are aimed at all companies in the cluster, not all of them necessarily use these characteristics for their benefit. For example, even though Company D was larger in size compared to other companies and despite the other companies' relative geographical proximity and support institutions' mediation, Company D showed no interest in maintaining collaborative relationships or exchanging knowledge with other companies in the cluster.

We also found that some companies showed the most robust development of specific OCS because they were more able to benefit from cluster characteristics. For example, Company B considered lectures organized by Sebrae on environmental and social awareness for employees important. Additionally, as a result of knowledge acquired in these lectures, the manager would implement actions in the company. These actions led to the development of capabilities related to alignment/motivation for sustainability (OCS4). Interviewee C, on the other hand, commented that the company currently does not show much interest in participating in these lectures and passing on the resulting environmental and social awareness to company employees.

Companies E and F, for example, are always in contact with some S System institutions to obtain support in developing process improvements. On the other hand, others did not demonstrate this involvement with institutions and lost the benefits of this support. Finally, only a few companies use proximity and interactions between companies to develop joint purchasing policies (Companies A, E, F and G) and input purchases and sales between some companies in the cluster (Companies $\mathrm{E}$ and F). In this sense, the present research indicates that companies aiming to develop more OCS can invest in promoting the specific benefits associated with the clusters in which they are inserted.

In this sense, the present research indicates that companies that wish to develop more OCS can invest in promoting the specific benefits associated with the clusters in which they operate. As highlighted by Yook, Choi and Suresh [69], all stakeholders need to understand the nature of capabilities and how they can help you to face challenges, and policymakers should encourage companies to get involved in sustainability.

Finally, the findings are in line with the previous literature, which considers that companies organized in networks tend to have benefits for the development of capabilities focused on sustainability [16-19]. Specifically, when focusing on cluster-type networks, this research extends the study by Hilliard and Jacobson [20]. They failed to state that companies located in clusters were more likely to develop capabilities to learn about environmental issues because maybe, the companies were not mature yet. Even in a specific context, we advance in this statement. Therefore, due to clusters characteristics, the companies studied learned to deal with recent challenges regarding how to develop organizational capabilities for sustainability in order to achieve some benefits.

\section{Conclusions, Contributions, Limitations and Suggestions for Future Research}

To answer how industrial clusters can foster developing organizational capabilities for sustainability (OCS), this paper develops a theoretical framework that relates clusters characteristics (CC) for OCS development, through the lens of benefits for companies that display these characteristics (Figure 1). To test the framework applicability, it was applied in seven companies in a footwear cluster to refine it and develop research propositions. The research findings contribute to both business theory and company management. 
The theoretical framework is the main contribution of this research. On one hand, it shows the characteristics of companies operating in industrial clusters. On the other hand, it presents organizational capabilities that allow companies to improve their corporate sustainability. However, as previously explained, these constructs were not yet explicitly related in the literature. Therefore, to fill this research gap, both constructs were related to each other in an unprecedented way through identifying benefits arising from cluster characteristics that mediate this relationship.

Therefore, the theoretical framework attempts to expand and contribute to studies in the area of industrial clusters, organizational capabilities and sustainability by presenting five main characteristics of companies inserted in clusters, which are related to seven OCS, through the lens of nine different benefits for companies operating in industrial clusters. Altogether, 29 potential relationships between these constructs can be explored in depth by researchers in the field, resulting in several research insights.

Adopting the case study as a research method is relevant and necessary to explore this topic, since most studies applied a quantitative approach [1]. From the empirical findings, it was possible to conclude that the cluster is mostly composed of companies that do not have sustainable improvements as their main business strategies. Even so, actions linked to sustainable improvements are found and OCS development has proved to be a crucial factor for companies achieving these and other actions linked to sustainability.

The second contribution concerns the development of the research propositions addressing the relationships between cluster characteristics and OCS. Those relationships were evidenced in the empirical study and corroborated by the literature. The refined framework also represents an important research contribution (Figure 3), because among all the relationships represented in the theoretical framework, only those that were evidenced in the empirical study are presented. Additionally, it highlights relationships that were strongly based on empirical findings (relationships identified in all companies studied).

One of the managerial implications is that through the framework (theoretical and refined), managers have a tool to support strategic decision making, which makes it possible to identify which cluster characteristics are related to OCS development in order to improve corporate sustainability of companies. These actions also point to what can be improved in the relationships between the other organizations in the cluster in order to improve corporate sustainability benefits.

This research also presents limitations and opportunities for further research, such as the decision to concentrate the empirical study in only one cluster. Further research could analyze other clusters in different industries and compare their results with those from this research. The research method adopted also represents another limitation, since the relationships identified and presented in the refined framework are linked to the reality and specificities of the studied footwear cluster. In this way, future research could, through a quantitative approach such as a survey or multicriteria methods, test and validate all 29 relationships identified in the theoretical framework and/or the 16 relationships found and presented in the research propositions and in the refined framework.

Future research may also use other research methods to explore and/or validate these relationships. For example, one can explore these relationships through a panel of experts or use quantitative and multicriteria methodologies.

Future research is also encouraged to advance the relationships that were operationalized in this research in order to (1) deeper explore each OCS and the relationships among them (Are there synergies between OCS? How can they potentialize each other?), (2) better understand the relationship between cluster benefits and OCS (How can the identified benefits of companies in industrial clusters promote OCS development? Under what conditions or context variables can this relationship be reinforced?) and to (3) investigate the impact of OCS for organizations (How do OCS in organizations inserted in industrial clusters contribute to corporate sustainability performance and competitive advantage?).

Finally, cluster characteristics, assessed based on the benefits arising from the agglomeration studied, allow companies to develop (and/or improve) specific OCS and 
consequently, their corporate sustainability. Therefore, these relationships, which have only recently been explored $[25,26]$, are now more known more in depth as a result of this research.

Author Contributions: Conceptualization, M.C.d.C.B., C.F.G. and S.N.M.; methodology, M.C.d.C.B., C.F.G. and S.N.M.; software, M.C.d.C.B.; validation, M.C.d.C.B., C.F.G. and S.N.M.; formal analysis, C.F.G. and S.N.M.; investigation, M.C.d.C.B., C.F.G. and S.N.M.; data curation, M.C.d.C.B.; writingoriginal draft preparation, M.C.d.C.B.; writing-review and editing, M.C.d.C.B., C.F.G. and S.N.M.; supervision, C.F.G. and S.N.M.; project administration, M.C.d.C.B., C.F.G. and S.N.M.; funding acquisition, M.C.d.C.B., C.F.G. and S.N.M. All authors have read and agreed to the published version of the manuscript.

Funding: This research was funded in part by the Coordenação de Aperfeiçoamento de Pessoal de Nível Superior-Brasil (CAPES)-Finance code: 1809142.

Conflicts of Interest: The authors declare no conflict of interest.

\section{Appendix A}

Table A1. Footwear cluster characteristics.

\begin{tabular}{ccll}
\hline CC & Grade & \multicolumn{1}{c}{ Description } & \multicolumn{1}{c}{ Evidence } \\
\hline CC1 & ST & $\begin{array}{l}\text { All companies are relatively } \\
\text { near one another due to the } \\
\text { small city circumference where } \\
\text { the cluster is located. }\end{array}$ & $\begin{array}{l}\text { E1: Three main agglomerations of companies exist: the industrial hub where } \\
\text { companies A, B, C, E and F are located; the industrial district (Company D); } \\
\text { and city neighborhoods (Company G). }\end{array}$ \\
\hline
\end{tabular}

E2: Companies A, B, C, E, F and G participate in periodic meetings organized by their union, their support institutions, lectures and fairs (attending together helps them reduce individual costs) and loan of inputs.

CC2 ST interact and collaborate with E3: Companies A, B, C, E and F issued a joint environmental license. each other.

E4: Companies A, E, F and G previously had joint purchases and companies E and $\mathrm{F}$ buy and sell inputs with other companies in the cluster. These last two policies are still incipient.

E5: The most prominent institutions are some organizations that make up the S system, which are Sebrae and Senai (National Service for Industrial Learning) These institutions organize fairs, lectures, events and trainings aimed at both businesspeople and employees. Additionally, Sesi (Social Service for Industry) aims to improve the work environment as well as health and safety at work.

All seven companies converge on the importance of support institutions in the studied cluster. The S System is deemed greatly important, while the state government, Alberto Franco Leather and Footwear School and the city's university are all deemed important but to a lesser degree.
E6: The Albano Franco Leather and Footwear school is also considered a technology center. It develops labor that companies absorb and provides services to companies (model development, use of new processes and technologies, etc.).

E7: We found that the city's university is not very representative because its support is punctual, which does not occur on an ongoing basis. Student design stemming from the design course (e.g., internships, material reuse and collection development) (Companies A, F, E and G) was evidenced.

E8: Concerning the state government, interviewees indicated that although a program aims to develop the cluster, it could be more active, since the aid is timely. The main government contributions are subsidies for companies to attend footwear fairs and developing the footwear pole (where Companies A, B, C, E and F are located). The land was ceded to businessmen and the government financed factory shed construction. The project was intended to strengthen small businesses in the cluster. 
Table A1. Cont.

\begin{tabular}{|c|c|c|c|}
\hline $\mathrm{CC}$ & Grade & Description & Evidence \\
\hline CC4 & $\mathrm{MO}$ & $\begin{array}{l}\text { No fierce competition exists } \\
\text { between the companies studied. } \\
\text { The most collaborative } \\
\text { companies that compete with } \\
\text { each other. }\end{array}$ & $\begin{array}{l}\text { E9: Most companies studied have different footwear production focuses } \\
\text { (Table 5) or different target markets. However, some companies in the cluster } \\
\text { have the same production focus and are directed at the same target market, } \\
\text { since the cluster has a relatively large number of companies. Even with shared } \\
\text { target markets, companies consider this competition more positive than } \\
\text { negative, since it encourages the improvement of products and processes. } \\
\text { E10: Company G's main competitors are major footwear brands' franchises. } \\
\text { Company A cites competition with informal footwear companies in Campina } \\
\text { Grande, which becomes unfair competition, because informal companies have } \\
\text { no charges, taxes and regulations because they simply copy formal companies' } \\
\text { models and processes. }\end{array}$ \\
\hline
\end{tabular}

E11: Since the city's inception in both history and culture, leather had already taken root as a raw material in footwear production. As a result, large footwear companies have settled in the city (Interviewee A).

Possesses a very strong CC5 ST historical and cultural identity in the city of Campina Grande.
E12: The cluster located in a city that has acquired an identity in footwear production with prominence in the country benefits companies' marketing and assists in market performance (Interviewees $F$ and $G$ ).

E13: Footwear identity among the population also stands out; people possess knowledge of their backgrounds and parents and grandparents who were shoemakers share such knowledge with future generations.

ST: Strong characteristic MO: Moderate characteristic WE: Weak characteristic; CC1: Geographical proximity of companies; CC2: Local level interactions and collaboration; formal and informal associations and networks; CC3: Associations/interactions with support institutions (public and private companies); CC4: Competition stimulus; CC5: Identity/sociocultural factors.

Table A2. Organizational capabilities for the sustainability of companies A, B, C, D, E, F and G.

\begin{tabular}{|c|c|c|c|c|}
\hline $\mathrm{C}$ & OCS & Grade & Description & Evidence \\
\hline & OCS1 & $\mathrm{MO}$ & $\begin{array}{l}\text { Acts jointly with others in the } \\
\text { cluster that facilitate } \\
\text { sustainability but in a limited } \\
\text { way. }\end{array}$ & $\begin{array}{l}\text { E1: Collaboration in a joint environmental license with } \\
\text { other cluster companies. } \\
\text { E2: Participation in a footwear union, attending a group of } \\
\text { fairs and attending periodic meetings that address } \\
\text { sustainability issues. } \\
\text { E3: Joint participation in lectures and trainings developed } \\
\text { mainly by System S support institutions during which } \\
\text { sustainability is the primary agenda. } \\
\text { E4a: Exchange of inputs with some companies in the } \\
\text { cluster when necessary and E4b: Joint purchases, which } \\
\text { improve logistical costs and reduce fuel consumption. }\end{array}$ \\
\hline A & OCS2 & $\mathrm{MO}$ & $\begin{array}{l}\text { Manages to acquire knowledge } \\
\text { linked to sustainability through } \\
\text { informal conversations with } \\
\text { other companies in the cluster } \\
\text { through lectures and seminars, } \\
\text { which System S support } \\
\text { institutions mainly develop. }\end{array}$ & $\begin{array}{l}\text { E5: Periodic meetings that address sustainability issues. } \\
\text { E6: Lectures and trainings developed mainly by System S } \\
\text { support institutions during which sustainability is the } \\
\text { primary agenda. } \\
\text { E7: The company exchanges information with others, for } \\
\text { example, information about suppliers who provide } \\
\text { recycled material for purchase. } \\
\text { E8: A specific supplier company demonstrates its } \\
\text { environmental concern when it requires environmental } \\
\text { licenses. }\end{array}$ \\
\hline
\end{tabular}

Possesses no innovation actions whose main objective is sustainability but indirectly

OCS3 MO participates in certain technologies in the production process that allow for specific sustainable improvements.

E9: Production process in the injection molding machines allows complete material reuse.

E10: Development of $100 \%$ cotton sneakers instead of using synthetic materials. 
Table A2. Cont.

\begin{tabular}{|c|c|c|c|c|}
\hline C & OCS & Grade & Description & Evidence \\
\hline \multirow{6}{*}{ A } & OCS4 & WE & $\begin{array}{l}\text { Environmental awareness } \\
\text { passed on to workers through } \\
\text { lectures and training developed } \\
\text { through The S System. The } \\
\text { company organizes internal } \\
\text { actions that create sustainability } \\
\text { but alignment for employees is } \\
\text { not very evident. }\end{array}$ & $\begin{array}{l}\text { E11: Lectures and training developed mainly by The S } \\
\text { System's support institutions where environmental and } \\
\text { social awareness topics are addressed. } \\
\text { E12: Separate garbage bins are used for waste within the } \\
\text { company, which even though simple, displays } \\
\text { environmental and social responsibility. }\end{array}$ \\
\hline & OCS5 & $\mathrm{NO}$ & $\begin{array}{l}\text { There are no capabilities linked } \\
\text { to sustainability-oriented } \\
\text { marketing }\end{array}$ & $\begin{array}{l}\text { E13: The interviewee affirms that no advertising mentions } \\
\text { the use of recycled material in shoes, since sharing this } \\
\text { information would hinder customers' interest in the } \\
\text { product and reduce sales. }\end{array}$ \\
\hline & OCS6 & $\mathrm{MO}$ & $\begin{array}{l}\text { Can adapt in a limited way to } \\
\text { environmental and social } \\
\text { sustainability issues imposed by } \\
\text { regulatory bodies.Has the } \\
\text { flexibility to follow market } \\
\text { trends, which can indirectly } \\
\text { bring sustainable improvements. }\end{array}$ & $\begin{array}{l}\text { E14: An environmental operating license was jointly } \\
\text { issued by SUDEMA and IBAMA. } \\
\text { E15: Compliance with employee health and safety } \\
\text { measures is imposed by the Ministry of Labor as well as } \\
\text { use of the PPRA and PCMSO programs. } \\
\text { E16: Exchange of traditional glue for a substance that does } \\
\text { not pollute water, which is water-based and reduces } \\
\text { workers' health risks. Same evidence as E10 cited above. }\end{array}$ \\
\hline & OCS7 & $\mathrm{MO}$ & $\begin{array}{l}\text { Does not have actions } \\
\text { specifically aimed at managing } \\
\text { sustainable operations but } \\
\text { indirectly makes specific } \\
\text { changes and improvements in } \\
\text { the production process, allowing } \\
\text { for timely sustainable } \\
\text { improvements. }\end{array}$ & $\begin{array}{l}\text { E17: Use of recycled material as a production input. } \\
\text { E18: Correct waste disposal. } \\
\text { Same evidence as E9 and E10 mentioned above. }\end{array}$ \\
\hline & OCS1 & $\mathrm{MO}$ & Same as Company A. & Same evidence as E1, E2, E3 and E4a (Company A). \\
\hline & OCS2 & $\mathrm{MO}$ & Same as Company A. & $\begin{array}{l}\text { Same evidence as E5, E6 and E7 (Company A). } \\
\text { E19: Lectures given by suppliers that present } \\
\text { environmentally responsible products and E19b: Manager } \\
\text { acquires knowledge through lectures and seminars and } \\
\text { shares this knowledge with company employees. }\end{array}$ \\
\hline
\end{tabular}

\section{No present innovation actions} that have a main objective of OCS3 WE achieving sustainability; indirectly, only one specific action was found.

B

OCS4 MO $\quad \begin{aligned} & \text { Environmental awareness is } \\ & \text { shared with employees through } \\ & \text { lectures and training developed } \\ & \text { through the S system and also } \\ & \text { periodically company organized. }\end{aligned}$

\begin{tabular}{cll}
\hline OCS5 & NO & Same as Company A. \\
\hline OCS6 & MO & $\begin{array}{l}\text { Can adapt to a limited extent to } \\
\text { environmental and social } \\
\text { sustainability issues imposed by } \\
\text { regulatory bodies. }\end{array}$ \\
\hline OCS7 & WE & $\begin{array}{l}\text { No actions specifically aimed at } \\
\text { managing sustainable } \\
\text { operations; indirectly, the } \\
\text { evidence is very timely. }\end{array}$ \\
\hline
\end{tabular}

E20: Development of a sneaker made with reusable material at a specific customer's request.

Same evidence as E11 (Company A).

E21: Lectures on environmental and social awareness for employees, organized by the company manager, who was once a professor at Senai (the cluster support agency).

E22: Donating a portion of one's trash for use in social work, such as recycling projects.

E23: The interviewee states that no periodic actions, such as advertisements that involve environmental issues exist in the company.

Same evidence as E14, E16 (Company A) and E20 (Company B).

Same evidence as E18 (Company A).

E24: The cutting process is still manual but executed in a manner that guarantees low waste. 
Table A2. Cont.

\begin{tabular}{|c|c|c|c|c|}
\hline C & OCS & Grade & Description & Evidence \\
\hline \multirow{7}{*}{$\mathrm{C}$} & OCS1 & $\mathrm{MO}$ & Same as Company A. & Same evidence as E1, E2, E3 and E4a (Company A). \\
\hline & OCS2 & $\mathrm{MO}$ & Same as Company A. & Same evidence as E5, E6 and E7 (Company A). \\
\hline & OCS3 & $\mathrm{MO}$ & Same as Company A. & Same evidence as E9 (Company A) and E20 (Company B). \\
\hline & OCS4 & WE & Same as Company A. & $\begin{array}{l}\text { Same evidence as E11 (Company A). } \\
\text { E25: In the past, support institutions organized more } \\
\text { lectures for company employees but currently the } \\
\text { company has no interest in these actions, because } \\
\text { management is concerned with pauses in production as a } \\
\text { result of the lectures. }\end{array}$ \\
\hline & OCS5 & $\mathrm{NO}$ & Same as Company A. & $\begin{array}{l}\text { Same evidence as E23. } \\
\text { E26: The use of recycled material in the manufacture of } \\
\text { sandals is passed on to customers but the information does } \\
\text { not become an attractive differential. }\end{array}$ \\
\hline & OCS6 & $\mathrm{MO}$ & Same as Company A. & $\begin{array}{l}\text { Same evidence as E14 and E15 (Company A). } \\
\text { E27: Construction to solve a water accumulation problem, } \\
\text { which the Ministry of Health requires. }\end{array}$ \\
\hline & OCS7 & $\mathrm{MO}$ & Same as Company A. & Same evidence as E9, E17 and E18 (Company A). \\
\hline \multirow{5}{*}{$\mathrm{D}$} & OCS1 & ST & $\begin{array}{l}\text { Displays a strong interaction } \\
\text { with customers and suppliers to } \\
\text { resolve sustainable issues. } \\
\text { Collaboration with supporting } \\
\text { institutions also stands out. } \\
\text { However, no collaborative } \\
\text { relationship exists between this } \\
\text { company and the others in the } \\
\text { cluster. }\end{array}$ & $\begin{array}{l}\text { E28: Specific supplier development management area. } \\
\text { E29: The company audits its suppliers and also undergoes } \\
\text { customer audits, which assess aspects of social and } \\
\text { environmental responsibility. } \\
\text { E30: Support institutions are responsible for training and } \\
\text { developing their labor force in environmental awareness. }\end{array}$ \\
\hline & OCS2 & ST & $\begin{array}{l}\text { Acquisition of knowledge in } \\
\text { sustainable issues occurs mainly } \\
\text { for customers, suppliers and } \\
\text { support institutions. }\end{array}$ & $\begin{array}{l}\text { E31: Meetings with customers and suppliers occur where } \\
\text { information on sustainability is exchanged. } \\
\text { E32: Audits between customers and suppliers that involve } \\
\text { sustainability issues occur. } \\
\text { Same evidence as E6 (Company A). }\end{array}$ \\
\hline & OCS3 & ST & $\begin{array}{l}\text { Innovation linked to } \\
\text { sustainability is considered } \\
\text { strong in the company; product } \\
\text { development and production } \\
\text { processes are strongly linked to } \\
\text { environmental concerns. }\end{array}$ & $\begin{array}{l}\text { E33: The company's brands launch collections related to } \\
\text { sustainability. } \\
\text { E34: Contracts with global auditing companies are in place, } \\
\text { which certify the compliance of products and processes } \\
\text { with environmental and social sustainability. }\end{array}$ \\
\hline & OCS4 & $\mathrm{MO}$ & $\begin{array}{l}\text { Environmental awareness is } \\
\text { shared with workers through } \\
\text { lectures and trainings developed } \\
\text { by the S System and several } \\
\text { company actions. }\end{array}$ & $\begin{array}{l}\text { Same evidence as E11 (Company A). } \\
\text { E35: Lectures on environmental and social awareness for } \\
\text { employees and other partners. } \\
\text { E36: Contraction of labor and services that have } \\
\text { environmental licenses, codes of ethics and practice social } \\
\text { responsibility. }\end{array}$ \\
\hline & OCS5 & $\mathrm{MO}$ & $\begin{array}{l}\text { Notable actions linked to } \\
\text { sustainable marketing exist. }\end{array}$ & $\begin{array}{l}\text { E37: The products (brands) have some bias linked to } \\
\text { sustainability issues. } \\
\text { E38: The company is audited by its main customers, so it is } \\
\text { able to meet market needs for sustainability. } \\
\text { E39: Advertising campaigns focused on sustainability are } \\
\text { periodically carried out. Through the company's website, } \\
\text { it was possible to observe such campaigns. }\end{array}$ \\
\hline
\end{tabular}


Table A2. Cont.

\begin{tabular}{|c|c|c|c|c|}
\hline $\mathrm{C}$ & OCS & Grade & Description & Evidence \\
\hline \multirow[b]{2}{*}{$\mathrm{D}$} & OCS6 & ST & $\begin{array}{l}\text { Can adapt to environmental and } \\
\text { social sustainability issues } \\
\text { imposed by regulatory bodies } \\
\text { and customers. }\end{array}$ & $\begin{array}{l}\text { E40: The company is audited by large customers that } \\
\text { impose codes of conduct related to environmental and } \\
\text { social sustainability. } \\
\text { E41: Presents all certifications and operating licenses } \\
\text { required by regulatory bodies. }\end{array}$ \\
\hline & OCS7 & ST & $\begin{array}{l}\text { The company's operational } \\
\text { processes are focused on issues } \\
\text { of environmental and social } \\
\text { responsibility. }\end{array}$ & $\begin{array}{l}\text { Same evidence as E18 (Company A). } \\
\text { E42: The products undergo laboratory analysis and do not } \\
\text { contain substances harmful to the worker's health or the } \\
\text { environment. } \\
\text { E43: The company has sustainable solid waste } \\
\text { management. They reuse water from the industrial process } \\
\text { and capture solar energy for parking. } \\
\text { E44: Waste transformation work. } \\
\text { E45: Development of supply chain sustainability, with an } \\
\text { emphasis on transforming industrial waste into new raw } \\
\text { materials for the production process. }\end{array}$ \\
\hline \multirow{7}{*}{$\mathrm{E}$} & OCS1 & $\mathrm{MO}$ & Same as Company A. & $\begin{array}{l}\text { Same evidence as E1, E2, E3, E4a and E4b (Company A). } \\
\text { E46: Purchase and sale of inputs with other cluster } \\
\text { companies. }\end{array}$ \\
\hline & OCS2 & $\mathrm{MO}$ & Same as Company A. & $\begin{array}{l}\text { Same evidence as E5, E6 and E7 (Company A). } \\
\text { E47: Supplier fairs for suppliers that present } \\
\text { environmentally responsible products, organized by } \\
\text { Sebrae. }\end{array}$ \\
\hline & OCS3 & $\mathrm{MO}$ & Same as Company A. & Same evidence as E9. \\
\hline & OCS4 & $\mathrm{MO}$ & $\begin{array}{l}\text { Environmental awareness is } \\
\text { shared with workers through } \\
\text { lectures and trainings developed } \\
\text { through the } S \text { system and } \\
\text { organized by the company; they } \\
\text { claim to pass this awareness on } \\
\text { to workers. }\end{array}$ & $\begin{array}{l}\text { Same evidence as E11 (company A). } \\
\text { E48: We try to pass environmental and social awareness to } \\
\text { workers, regarding the waste, reuse and disposal of } \\
\text { materials. } \\
\text { E49: The company claims that its material is } 99 \% \text { recyclable } \\
\text { and employees are aware of the importance of this. }\end{array}$ \\
\hline & OCS5 & $\mathrm{NO}$ & Same as Company A. & $\begin{array}{l}\text { Same evidence as E23 (Company B). } \\
\text { E50: Sebrae provides training and works within companies } \\
\text { to take sustainable footwear to events alongside marketing, } \\
\text { which presents Paraíba's shoes as sustainable footwear. } \\
\text { However, no such internal capacity exists within the } \\
\text { company. }\end{array}$ \\
\hline & OCS6 & $\mathrm{MO}$ & Same as Company B. & $\begin{array}{l}\text { Same evidence as E14 and E16. } \\
\text { E51: The company states that it is necessary, it seeks } \\
\text { Sebrae's expertise to develop a program to cover each } \\
\text { need, which is then presented to all cluster companies. }\end{array}$ \\
\hline & OCS7 & $\mathrm{MO}$ & Same as Company A. & $\begin{array}{l}\text { Same evidence as E16 and E17. } \\
\text { E52: Participation in training within the factory or in } \\
\text { support institutions, developed with a focus on } \\
\text { productivity, use of raw materials, labor and personnel } \\
\text { training. } \\
\text { E53: Using only synthetic material when producing shoes. } \\
\text { E54: Brazil's most productive program to reuse stored, raw } \\
\text { materials, which was implemented in the company this } \\
\text { past year and this year. The company was used to pilot the } \\
\text { program and it obtained good results. }\end{array}$ \\
\hline
\end{tabular}


Table A2. Cont.

\begin{tabular}{|c|c|c|c|c|}
\hline C & OCS & Grade & Description & Evidence \\
\hline \multirow{7}{*}{$\mathrm{F}$} & OCS1 & $\mathrm{MO}$ & Same as Company A. & $\begin{array}{l}\text { Same evidence as E1, E2, E3 E4a and E4b (Company A). } \\
\text { E55: Sale and loan of the waste produced in the company, } \\
\text { which are given to other companies. }\end{array}$ \\
\hline & OCS2 & $\mathrm{MO}$ & Same as Company A. & $\begin{array}{l}\text { Same evidence as E5, E6 and E7 (company A) and E19 } \\
\text { (company B). }\end{array}$ \\
\hline & OCS3 & $\mathrm{MO}$ & Same as Company A. & Same evidence as E9. \\
\hline & OCS4 & $\mathrm{MO}$ & $\begin{array}{l}\text { Environmental awareness } \\
\text { passed on to workers through } \\
\text { lectures and trainings developed } \\
\text { by the S System. Internal, } \\
\text { punctual actions, organized by } \\
\text { the company. }\end{array}$ & $\begin{array}{l}\text { Same evidence as E11 (Company A) and E22 (Company B). } \\
\text { E56: As a motivational measure linked to environmental } \\
\text { awareness, the company separates money collected from } \\
\text { selling garbage, so that at each year's end, the company } \\
\text { can buy food baskets as gifts for employees so that they } \\
\text { can see the positive effects of encouraging sustainability. }\end{array}$ \\
\hline & OCS5 & $\mathrm{NO}$ & Same as Company A. & Same evidence as E23 (Company B). \\
\hline & OCS6 & $\mathrm{MO}$ & Same as Company B. & Same evidence as E14, E15 and E16. \\
\hline & OCS7 & $\mathrm{MO}$ & Same as Company A. & $\begin{array}{l}\text { Same evidence as E9 and E18 (Company A). } \\
\text { E57: Some processes have passed and are undergoing } \\
\text { improvements, aiming to better use inputs and thus reduce } \\
\text { waste, such as improving cutting knives to allow an almost } \\
\text { zero flap and improving machines to reduce line pieces. } \\
\text { E58: Decrease in the use of leather in shoe production. }\end{array}$ \\
\hline \multirow{7}{*}{ G } & OCS1 & $\mathrm{MO}$ & Same as Company A. & $\begin{array}{l}\text { Same evidence as E1, E2, E3 and E4a and E4b (Company } \\
\text { A). }\end{array}$ \\
\hline & OCS2 & $\mathrm{MO}$ & Same as Company A. & $\begin{array}{l}\text { Same evidence as E5, E6 and E7 (Company A) and E47 } \\
\text { (Company E). } \\
\text { E59: Seeks to know your suppliers and the way they work. }\end{array}$ \\
\hline & OCS3 & $\mathrm{MO}$ & Same as Company A. & $\begin{array}{l}\text { E60: The product is constantly changing and improving its } \\
\text { design because it is a differentiated line in the city. Then, } \\
\text { leather was replaced by fabric, as the main input in the } \\
\text { production of shoes, bags and accessories. } \\
\text { E61: The company has already worked in association with } \\
\text { a local cooperative to produce a line of colored cotton } \\
\text { products. }\end{array}$ \\
\hline & OCS4 & WE & Same as Company A. & Same evidence as E11 (Company A) and E22 (Company B). \\
\hline & OCS5 & $\mathrm{NO}$ & Same as Company A. & Same evidence as E23 (Company B). \\
\hline & OCS6 & $\mathrm{MO}$ & Same as Company B. & Same evidence as E14, E15 and E16 (Company A). \\
\hline & OCS7 & WE & Same as Company B. & Same evidence as E18 (Company A) and E24 (Company B). \\
\hline
\end{tabular}

ST: Strong characteristic MO: Moderate characteristic WE: Weak characteristic; CC1: Geographical proximity of companies; CC2: Local level interactions and collaboration; formal and informal associations and networks; CC3: Associations/interactions with support institutions (public and private companies); CC4: Competition stimulus; CC5: Identity/sociocultural factors.

\section{References}

1. Da Cunha Bezerra, M.C.; Gohr, C.F.; Morioka, S.N. Organizational capabilities towards corporate sustainability benefits: A systematic literature review and an integrative framework proposal. J. Clean. Prod. 2020, 247. [CrossRef]

2. Gelhard, C.; von Delft, S. The role of organizational capabilities in achieving superior sustainability performance. J. Bus. Res. 2016, 69, 4632-4642. [CrossRef]

3. Albort-Morant, G.; Leal-Millán, A.; Cepeda-Carrión, G. The antecedents of green innovation performance: A model of learning and capabilities. J. Bus. Res. 2016, 69, 4912-4917. [CrossRef]

4. Lozano, R.; Carpenter, A.; Huisingh, D. A review of "theories of the firm" and their contributions to Corporate Sustainability. J. Clean. Prod. 2015, 106, 430-442. [CrossRef]

5. Hart, S.L. A Natural-Resource-Based View of the Firm. Acad. Manag. Rev. 1995, 20, 986-1014. [CrossRef]

6. Bhattarai, C.R.; Kwong, C.C.Y.; Tasavori, M. Market orientation, market disruptiveness capability and social enterprise performance: An empirical study from the United Kingdom. J. Bus. Res. 2019, 96, 47-60. [CrossRef] 
7. Johnson, M.P. Knowledge acquisition and development in sustainability-oriented small and medium-sized enterprises: Exploring the practices, capabilities and cooperation. J. Clean. Prod. 2017, 142, 3769-3781. [CrossRef]

8. Lai, W.H.; Lin, C.C.; Wang, T.C. Exploring the interoperability of innovation capability and corporate sustainability. J. Bus. Res. 2015, 68, 867-871. [CrossRef]

9. Sharma, S.; Vredenburg, H. Proactive corporate environmental strategy and the development of competitively valuable organizational capabilities. Strateg. Manag. J. 1998, 19, 729-753. [CrossRef]

10. Annunziata, E.; Pucci, T.; Frey, M.; Zanni, L. The role of organizational capabilities in attaining corporate sustainability practices and economic performance: Evidence from Italian wine industry. J. Clean. Prod. 2018, 171, 1300-1311. [CrossRef]

11. Salim, N.; Ab Rahman, M.N.; Abd Wahab, D. A systematic literature review of internal capabilities for enhancing eco-innovation performance of manufacturing firms. J. Clean. Prod. 2019, 209, 1445-1460. [CrossRef]

12. Amui, L.B.L.; Jabbour, C.J.C.; de Sousa Jabbour, A.B.L.; Kannan, D. Sustainability as a dynamic organizational capability: A systematic review and a future agenda toward a sustainable transition. J. Clean. Prod. 2017, 142, 308-322. [CrossRef]

13. Gabler, C.B.; Richey, R.G.; Rapp, A. Developing an eco-capability through environmental orientation and organizational innovativeness. Ind. Mark. Manag. 2015, 45, 151-161. [CrossRef]

14. Yu, W.; Ramanathan, R. Environmental management practices and environmental performance the roles of operations and marketing capabilities. Ind. Manag. Data Syst. 2016, 116, 1201-1222. [CrossRef]

15. Galdeano-Gómez, E.; Céspedes-Lorente, J.; Martínez-del-Río, J. Environmental performance and spillover effects on productivity: Evidence from horticultural firms. J. Environ. Manag. 2008, 88, 1552-1561. [CrossRef]

16. Beske, P. Dynamic capabilities and sustainable supply chain management. Int. J. Phys. Distrib. Logist. Manag. 2012, 42, 372-387. [CrossRef]

17. Bowen, F.E.; Cousins, P.D.; Lamming, R.C.; Faruk, A.C. The role of supply management capabilities in green supply. Prod. Oper. Manag. 2001, 10, 174-189. [CrossRef]

18. Chen, I.J.; Kitsis, A.M. A research framework of sustainable supply chain management: The role of relational capabilities in driving performance. Int. J. Logist. Manag. 2017, 28, 1454-1478. [CrossRef]

19. Reuter, C.; Foerstl, K.; Hartmann, E.; Blome, C. Sustanable Global Supplier Management: The Role of Dynamic Capabilities in Achieving Competitive Advantage. J. Supply Chain Manag. 2010, 46, 45-63. [CrossRef]

20. Hilliard, R.; Jacobson, D. Cluster versus Firm-specific Factors in the Development of Dynamic Capabilities in the Pharmaceutical Industry in Ireland: A Study of Responses to Changes in Environmental Protection Regulations. Reg. Stud. 2011, 45, 1319-1328. [CrossRef]

21. Perez-Aleman, P. Regulation in the Process of Building Capabilities: Strengthening Competitiveness While Improving Food Safety and Environmental Sustainability in Nicaragua. Polit. Soc. 2013, 41, 589-620. [CrossRef]

22. Martínez-del-Río, J.; Céspedes-Lorente, J. Competitiveness and Legitimation: The Logic of Companies going Green in Geographical Clusters. J. Bus. Ethics 2014, 120, 131-146. [CrossRef]

23. Porter, M.E. Clusters and the New Economics of Competition. Harv. Bus. Rev. 1998, 77-90.

24. Faustino, C.D.A.; Gohr, C.F.; Santos, L.C. An approach for evaluating collaboration attributes in cluster-based companies. Int. J. Prod. Res. 2019, 57, 2356-2371. [CrossRef]

25. Puppim de Oliveira, J.A.; Jabbour, C.J.C. Environmental Management, Climate Change, CSR, and Governance in Clusters of Small Firms in Developing Countries: Toward an Integrated Analytical Framework. Bus. Soc. 2017, 56, 130-151. [CrossRef]

26. McLennan, C.L.J.; Becken, S.; Watt, M. Learning through a cluster approach: Lessons from the implementation of six Australian tourism business sustainability programs. J. Clean. Prod. 2016, 111, 348-357. [CrossRef]

27. Daddi, T.; Iraldo, F. The effectiveness of cluster approach to improve environmental corporate performance in an industrial district of SMEs: A case study. Int. J. Sustain. Dev. World Ecol. 2016, 23, 163-173. [CrossRef]

28. Pavlovich, K.; Akoorie, M. Innovation, sustainability and regional development: The Nelson/Marlborough seafood cluster, New Zealand. Bus. Strateg. Environ. 2010, 19, 377-386. [CrossRef]

29. Lund-Thomsen, P.; Lindgreen, A.; Vanhamme, J. Special Issue on Industrial Clusters and Corporate Social Responsibility in Developing Countries. J. Bus. Ethics 2016, 133, 5-8. [CrossRef]

30. Jabbour, C.J.C.; Puppim-De-Oliveira, J.A. Barriers to environmental management in clusters of small businesses in Brazil and Japan: From a lack of knowledge to a decline in traditional knowledge. Int. J. Sustain. Dev. World Ecol. 2012, 19, 247-257. [CrossRef]

31. Amato Neto, J.; Barros, M.C.L. Co-operation for the sustainable development in industrial clusters: A Brazilian case study. Int. Annu. EurOMA Conf. 2010, 17, 1-10.

32. Martin, S.; Mayer, H. Introduction to Focus Section the Various Faces of Sustainability. Econ. Dev. Q. 2008, 22, 272-276. [CrossRef]

33. Li, H.; de Zubielqui, G.C.; O'Connor, A. Entrepreneurial networking capacity of cluster firms: A social network perspective on how shared resources enhance firm performance. Small Bus. Econ. 2015, 45, 523-541. [CrossRef]

34. Hervás-Oliver, J.L.; Albors-Garrigós, J. Do clusters capabilities matter? An empirical application of the resource-based view in clusters. Entrep. Reg. Dev. 2007, 19, 113-136. [CrossRef]

35. Hervas-Oliver, J.L.; Albors-Garrigos, J. The role of the firm's internal and relational capabilities in clusters: When distance and embeddedness are not enough to explain innovation. J. Econ. Geogr. 2009, 9, 263-283. [CrossRef]

36. Li, J.; Geng, S. Industrial clusters, shared resources and firm performance. Entrep. Reg. Dev. Int. J. 2012, 24, 357-381. [CrossRef] 
37. Dyer, J.H.; Singh, H. The Relational View: Cooperative Strategy and Sources of Interorganizational Competitive Advantage. Acad. Manag. Rev. 1998, 23, 660. [CrossRef]

38. Lavie, D. The competitive advantage of interconnected firms: An extension of the resource-based view. Acad. Manag. Rev. 2006, 31, 638-658. [CrossRef]

39. Hervas-Oliver, J.-L.; Gonzalez, G.; Caja, P.; Sempere-Ripoll, F. Clusters and Industrial Districts: Where is the Literature Going? Identifying Emerging Sub-Fields of Research. Eur. Plan. Stud. 2015, 4313, 1-46. [CrossRef]

40. Cohen, W.M.; Levinthal, D.A. Absorptive Capacity: A new perspective on learning and innovation. Adm. Sci. Q. 1990, 35, 128-152. [CrossRef]

41. Oliveira, G.M.; da Silva, A.B. How can inter-organizational learning and dynamic managerial capability improve cluster performance? Rev. Eletrônica Estratégia Negócios 2020, 13, 145-168. [CrossRef]

42. De Almeida, J.M.G.; Gohr, C.F.; Morioka, S.N.; Medeiros da Nóbrega, B. Towards an integrative framework of collaborative capabilities for sustainability: A systematic review and research agenda. J. Clean. Prod. 2021, 279. [CrossRef]

43. Hart, S.L.; Dowell, G. A Natural-Resource-Based View of the Firm: Fifteen Years After. J. Manage. 2011, 37, 1464-1479. [CrossRef]

44. Amit, R.; Schoemaker, P.J.H. Strategic Assets and Organizational Rent. Strateg. Manag. J. 1993, 14, 33-46. [CrossRef]

45. Helfat, C.E.; Peteraf, M.A. The dynamic resource-based view: Capability lifecycles. Strateg. Manag. J. 2003, 24, 997-1010. [CrossRef]

46. Pinkse, J.; Kuss, M.J.; Hoffmann, V.H. On the implementation of a 'global' environmental strategy: The role of absorptive capacity. Int. Bus. Rev. 2010, 19, 160-177. [CrossRef]

47. Marra, A.; Antonelli, P.; Pozzi, C. Emerging green-tech specializations and clusters-A network analysis on technological innovation at the metropolitan level. Renew. Sustain. Energy Rev. 2017, 67, 1037-1046. [CrossRef]

48. Boschma, R.A. Proximity and innovation: A critical assessment. Reg. Stud. 2005, 39, 61-74. [CrossRef]

49. Schmitz, H. On the Clustering of Small Firms. IDS Bull. 1992, 23, 64-69. [CrossRef]

50. Altenburg, T.; Meyer-Stamer, J. How to Promote Clusters: Policy Experimences from Latin America. World Dev. 1999, 27, 1693-1713. [CrossRef]

51. Spekkink, W. Building capacity for sustainable regional industrial systems: An event sequence analysis of developments in the Sloe Area and Canal Zone. J. Clean. Prod. 2015, 98, 133-144. [CrossRef]

52. Lund-Thomsen, P.; Lindgreen, A.; Vanhamme, J. Industrial Clusters and Corporate Social Responsibility in Developing Countries: What We Know, What We do not Know, and What We Need to Know. J. Bus. Ethics 2016, 133, 9-24. [CrossRef]

53. Zhou, Y.; Hong, J.; Zhu, K.; Yang, Y.; Zhao, D. Dynamic capability matters: Uncovering its fundamental role in decision making of environmental innovation. J. Clean. Prod. 2018, 177, 516-526. [CrossRef]

54. Yin, R.K. Estudo de Caso: Planejamento e Métodos, 5th ed.; Nuance: Porto Alegre, Brazil; Bookman: Porto Alegre, Brazil, 2015.

55. Creswell, J.W. PROJETO DE PESQUISA Métodos Qualitativo, Quantitativo e Misto, 2nd ed.; Artmed: Porto Alegre, Brazil, 2007; ISBN 9788536308920.

56. Eisenhardt, K.M.; Graebner, M.E. Theory building from cases: Opportunities and challenges. Acad. Manag. J. 2007, 50, 25-32. [CrossRef]

57. Serviço Brasileiro de Apoio às Micro e Pequenas Empresas (Sebrae); Banco Interamericano de Desenvolvimento (BID); Projeto Promos/Sebrae/BID. Sebrae Metodologia de Desenvolvimento de Arranjos Produtivos Locais—Projeto Promos-Sebrae-BID. Sebrae: Brasilia, Brazil, 2004; p. 292. Available online: https:/ /www.worldcat.org/title/metodologia-de-desenvolvimento-dearranjos-produtivos-locais-projeto-promos-sebrae-bid-versao-20/oclc/683310413 (accessed on 1 September 2020).

58. Associação Brasileira de Calçados. Relatório Anual de Atividades I; Abicalçados: Novo Hamburgo/RS, Brazil, $2019 ;$ pp. 1-68.

59. Associação Brasileira de Calçados. Relatório Anual de Atividades II; Abicalçados: Novo Hamburgo/RS, Brazil, 2018 ; pp. 1-72.

60. Lemos, C.; Palhano, A. Arranjo Produtivo Coureiro-Calçadista de Campina Grande/PB. Nota Técnica 2000. [CrossRef]

61. Santos, A.M.M.M.; Corrêa, A.R.; Alexim, F.M.B.; Peixoto, G.B.T.P. Deslocamento de Empresas Para os Estados do Ceará e da Bahia: O Caso da Indústria Calçadista; BNDES Setorial: Rio de Janeiro, Brazil, 2002; Volume 15, pp. 63-68.

62. Guidolin, S.M.; da Costa, A.C.R.; da Rocha, É.R.P. Indústria Calçadista e Estratégias de Fortalecimento da Competitividade; BNDES Setorial: Rio de Janeiro, Brazil, 2010; Volume 31, pp. 147-148.

63. Banco Nacional de Desenvolvimento Econômico e Social (BNDES). A Indústria Calçadista No Brasil; BNDES Setorial: Rio de Janeiro, Brazil, 2006; pp. 1-4.

64. Dangelico, R.M.; Pontrandolfo, P.; Pujari, D. Developing sustainable new products in the textile and upholstered furniture industries: Role of external integrative capabilities. J. Prod. Innov. Manag. 2013, 30, 642-658. [CrossRef]

65. Hofmann, K.H.; Theyel, G.; Wood, C.H. Identifying Firm Capabilities as Drivers of Environmental Management and Sustainability Practices-Evidence from Small and Medium-Sized Manufacturers. Bus. Strateg. Environ. 2012, 21, 530-545. [CrossRef]

66. Van Hoof, B.; Thiell, M. Collaboration capacity for sustainable supply chain management: Small and medium-sized enterprises in Mexico. J. Clean. Prod. 2014, 67, 239-248. [CrossRef]

67. Ketata, I.; Sofka, W.; Grimpe, C. The role of internal capabilities and firms' environment for sustainable innovation: Evidence for Germany. R D Manag. 2014, 45, 60-75. [CrossRef]

68. Torugsa, N.A.; O'Donohue, W.; Hecker, R. Capabilities, Proactive CSR and Financial Performance in SMEs: Empirical Evidence from an Australian Manufacturing Industry Sector. J. Bus. Ethics 2012, 109, 483-500. [CrossRef]

69. Yook, K.H.; Choi, J.H.; Suresh, N.C. Linking green purchasing capabilities to environmental and economic performance: The moderating role of firm size. J. Purch. Supply Manag. 2017, 24, 326-337. [CrossRef] 
70. Ko, W.W.; Liu, G. Environmental Strategy and Competitive Advantage: The Role of Small- and Medium-Sized enterprises' Dynamic Capabilities. Bus. Strateg. Environ. 2017, 26, 584-596. [CrossRef]

71. Lee, S.Y.; Klassen, R.D. Drivers and enablers that foster environmental management capabilities in small- and medium-sized suppliers in supply chains. Prod. Oper. Manag. 2008, 17, 573-586. [CrossRef] 